\title{
SZEMLE
}

\section{ERNYEY GYULA „DESIGN. TERVEZÉSELMÉLET ÉS TERMÉKFORMÁLÁS 1750-2010" CÍMÜ, AZ MTA DOKTORA CÍMÉRT BENYÚJTOTT ÉRTEKEZÉSÉNEK VITÁJA}

A nyilvános vita 2015. június 25-én folyt. A Bíráló Bizottság elnöke Finta József, titkára Krähling János, tagjai Cságoly Ferenc, Passuth Krisztina, Petró Bálint, Vámossy Ferenc és Vukoszávlyev Zorán voltak. A hivatalos bírálók Bonta János, Sisa József és Simon Mariann, bírálatukat és Ernyey Gyula válaszát is közöljük. A sikeresen zárult védés a design szakterület első doktori védése volt a Magyar Tudományos Akadémián.

\section{AZ AKADÉMIAI DOKTORI ÉRTEKEZÉS TÉZISEI}

\section{KUTATÁSI CÉL ÉS MÓDSZER, TUDOMÁNYOS ELÖZMÉNYEK}

Az ember társadalmi fejlődése ősi fokától kezdve tárgyakat készít és alkalmaz, amelyek nem egyszerủen a túlélésre, vagy a túlélés megkönnyítésére és kényelmesebbé tételére szolgálnak. Az ember nembeli lényegéből adódóan a tárgyak mindenkor különböző célokat testesítenek meg; megmutatják szaktudását, alakítják önazonosságát, és „egyben előállítóik és használóik elöállítói és használói” is [4].

Ebben a több ezer éves bonyolult kapcsolatban új időszámítás kezdődött az első ipari forradalommal. A hosszú „mezőgazdasági kor” [5] után, amelyben a termőföld és termékei képezték elsősorban az egyes nemzetek megélhetésének alapját, az országok gazdagságát, megkezdődött az ipar, mégpedig - az addigi kézmüves és manufakturális ipar helyébe lépő - gyáripar és az általa elöállított termékek drámai szerepvállalása. Ahogyan az építészettörténészként ismert Siegfried Giedion fogalmazta híres könyve címében: Mechanization Takes Command [11]. Ez az előállításon túl az egyéni és a társadalmi élet majd minden területének új kapcsolatát és müködését jelentette a tervezéstől a gyártáson és az eladáson át a használatig bezáróan. Azóta a tudományos-technikai forradalom eredményeképpen a gyáripar 
termelékenysége óriásira nőtt, és a gyártmányok hatalmas mennyisége és választéka jött létre; ezzel együtt az előállított termékek megjelenésmódja sokféle változáson ment keresztül. A változások okainak és jellemzőinek, hatásának megnyugtató, tudományos számbavétele azonban nem történt meg valójában. Ennek elmaradása többféleképpen magyarázható az egyes kultúrákban és országokban, de nem utolsósorban önmagából, a tárgyak létezését biztosító forma: a design összetettségéből és relatív autonómiájából adódott. Nem egynemü, hanem többféle értéket képvisel a használat megjelenésmódjából - az öt érzék révén - létrejövő formaminőség, amivel találkozunk a tárgy müködtetése során. Ebben az összetett minőségben a vizuális karakter - a látás - kétségkívül meghatározó szerepü, hiszen többnyire elöször általa ismerkedünk meg a tárggyal és mondunk elsődleges ítéletet, de mégsem egyedüli

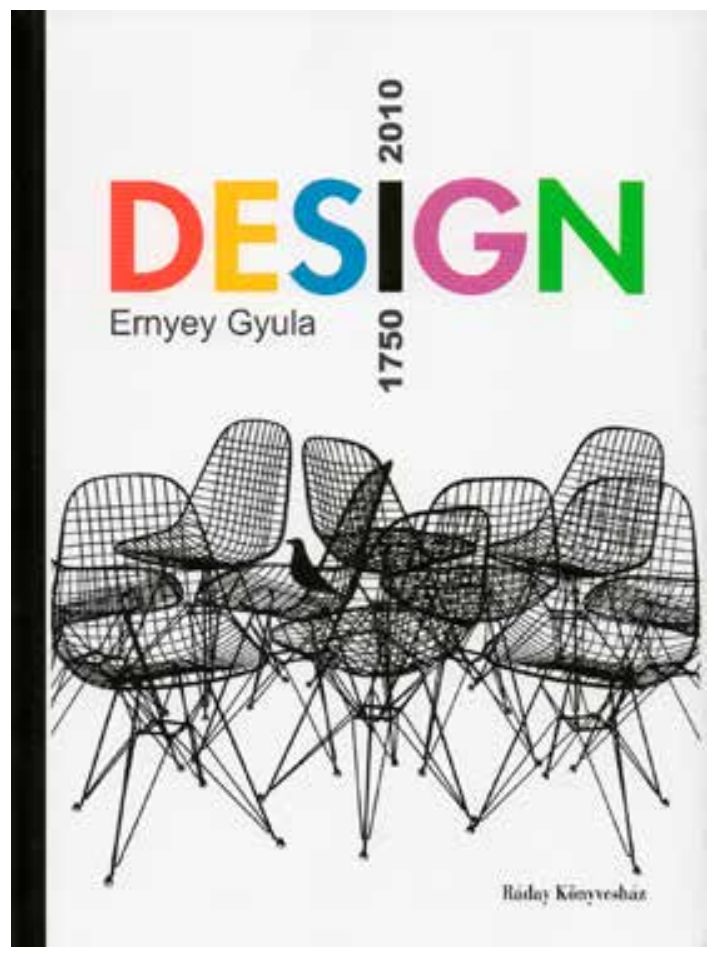

tényező, hiszen a közvetlen - fizikai - kapcsolat tapintás révén jön létre. A tárgy müszaki vagy gazdasági szempontú vizsgálata sem tudósít kényelmes használhatóságáról és biztonságos kezelhetőségéről, nem szólva az újabban általánosan megkövetelt környezetbarát kialakításról. A különböző tényezők szeparált - nem együttes - és történeti változásukat figyelmen kívül hagyó, egyoldalú vizsgálatai nem is hoztak megnyugtató eredményt mind ez ideig. 
Ebben a dolgozatban az ipari tárgyak - a használati folyamatban beteljesülö - formai minőségét alkotó tényezők együttes történeti elemzésére tettem kísérletet. Vizsgálatom elsősorban a gyártmányformákra irányult, alapvetően konkrét mủvekre, a design történetét leginkább meghatározó tartós fogyasztási és termelési javakra, nemzetközileg használt angol megnevezésükkel: a product design és az engineering based product design, avagy engineering industrial design területéhez tartozó termékekre. A tárgyi világ óriási halmaza alakulásának megértéséhez azonban a szükséges mértékben foglalkoztam a tervezéselmélet legfontosabb felismeréseivel, valamint intézmények: iskolák, gyárak és tervezőmühelyek, továbbá az eredményeket bemutató világkiállítások szerepével is. Kutatásom időben és helyenként változó szempontú a vizsgált korszak értékfelfogása, a formaminőséget alkotó tényezők sokszínüsége és változása szerint.

Dolgozatom több mint négy évtizede elkezdett kutatásaim összefoglalása. Alapgondolatai a hatvanas évek második felében, a modernizáció hazai új hulláma idején születtek meg a tárgyalkotás elméletének a téralkotás, az építészet elméletének színvonalához való közelítés közvetlen céljával, a magyar nyelvủ szakirodalom megalapozása szándékával, és a rákövetkező évtizedek során nyerték el mai formájukat ([S1], [S2], [S3], majd [S13]). Amikorra megjelentek azok az alapozó történeti és elméleti müvek, elsősorban is a német, angol és amerikai szakirodalomban (Wend Fischer és Reyner Banham első építészeti és tárgytervezési számvetései [9], [1]; Raymond Loewy és Henry Dreyfuss hitvalláskötetei [16], [7] ; Herbert Lindinger összegező tanulmányai [15]), a szakterület nemzetközi szervezeteinek állásfoglalásai (ICSID 1965) a design értelmezéséről, amelyek nemcsak megingatták a tervezés és a termékforma addigi egyoldalú - múvészeti vagy éppen gazdasági - értelmezéseit (Herbert Read és Nikolaus Pevsner [27] és [24], illetve John Gloag [12]), de valósabb új alternatívákat is kínáltak helyettük. Erre az idöre egyre több olyan könyv került kiadásra az ipari tárgyalkotás egyetemes és nemzeti történeti eredményeiről is ([2], [5], illetve [17]), amelyek tényszerüen cáfolták a - csupán részben helytálló korábbi állításokat. Mindinkább világossá vált, hogy az addig elterjedt egydimenziós - müszaki, mủvészeti vagy kereskedelmi - értelmezés tudományosan nem tartható, a tárgyalkotás, avagy - az egyre általánosabban használt angol megnevezés szerint - a design minőségének megértéséhez új megközelítésre van szükség. A többféle, többdimenziós értéket képviselő minőségfelfogás megerösödéséhez a már sikeresen használt tudományok (ergonómia, értékelemzés, majd értéktervezés) mellett az újabbak (információelmélet, rendszerelmélet) járultak hozzá gyümölcsözőn. A felszíni látvány elé egyre inkább a „belső látás”, a több érzék nyomán előálló észlelet minőségének igénye tolult, hangsúlyosan kiegészülve a használat időszükségletével, folyamatjellegével (Jan Kotík és Bogdan Czekaluk révén a hatvanas években [S2]). Az ipari termelés növekedésével együtt mind nagyobbá váló - és sürgetően megoldandó - ökológiai és szociális problémakörök (Victor Papanek [23], Ernst F. Schumacher [29]) újabb dimenzióval gazdagították-tágították a gyártmánytervezés korábbi szempontrendszerét. 
Az egyetemes designtörténet irodalmának feldolgozása mellett kutatásaim során bejártam az ipari tárgyalkotás ismereteinek elsődleges forráshelyeit. A legfontosabb nemzetközi tárgygyüjteményekben tanulmányoztam a történeti anyagot a budapesti Országos Müszaki Múzeumtól és Iparmüvészeti Múzeumtól, a londoni Science Museumtól és Victoria and Albert Museumtól, valamint a Smithsonian Institution washingtoni és New York-i gyüjteményeitől, az ugyancsak New York-i Museum of Modern Art, a dearboni Ford Museumtól kezdve a koppenhágai Danske Kunstindustrimuseeten, a prágai Technické Muzeumon és Uméleckoprůmyslové Muzeumon, a brnói Moravská Galerien át a milánói Museo Nazionale della Scienza e della Technologia 'Leonardo da Vinci'-ig és a tokiói Science Museumig bezáróan. Az egykori kortárs - mára már történeti - eredményeket az ipari bemutatókon túl a vezető nagyvállalatoknál (Olivetti, Zanotta, Cassina, Mitsubishi és mások), jeles tervezőknél (Gio Ponti, Marco Zanuso, Ettore Sottsass, Andrea Branzi, Pierre Paulin, Roger Tallon, Olivier Mourge, Sori Yanagi, Kenji Ekuan, Andrzej Pawlowski és mások) és tervezőirodákban (Giorgio Giugiaro / Italdesign, Torinó; John Macsay, Chicago; Raymond Loewy, Párizs; Pentagram, London; Sharp, Osaka) ismerhettem meg közvetlenül. A designtörténet egyre nagyobb számban előkerülő különböző - a komplex értelmezés szerint nem egymást kizáró, hanem egymással összeépülö - tárgyainak és elméleti eredményeinek megismerése nyomán vállalkoztam a meglevő részek összeillesztésére, a köztük lévő hiányok felkutatására, majd az eredmények nagyobb egységgé szervezésére és végül téziseim megfogalmazására a nyolcvanas évek elején - az ipari fejlődés perifériáján. Hátrányomból előny is származott, mivel voltaképpen kívülállóként elfogulatlanabbul és egyszersmind - Szabolcsi Bence, illetve Kosáry Domokos perifériaelméletének megfelelően - késztettebben láthattam munkához; nehezebb körülmények között, de talán befogadóbban az érdekelt ipari nagyhatalmak (angol, német, francia, amerikai és szovjet) szakirodalmi képviselőinél. Kutatómunkámban nagy segítségemre volt építész mestereim, Szrogh György és Pogány Frigyes szellemisége, továbbá tervezői és oktatói tevékenységem, a hallgatókkal folytatott több évtizedes párbeszéd.

\section{TÉZISEK}

1. Az ember egyik legalapvetőbb sajátossága tárgyalkotó képessége, amelynek révén valójában eltárgyiasítja magát. Minden általa előállított tárgy különféle döntések eredménye, értékválasztás az elvégzendő célok, feladatok alapján. Ezek a célok, funkciók összefoglalóan leginkább ,anyagi és szellemi”, „funkcionális és reprezentatív” vagy „,instrumentális és kommunikációs” csoportosításokban ismertek; súlyuk és szerepük a tárgytípusok szerint - sőt azokon belül is - különbözhet az alkotó(k), a kor és a környezet igényei, a használt anyagok és technológiák által is. A tárgyakban tárgyiasított célok, funkciók egyben értékhordozók, amelyeknek valóságos, érzéki-konkrét kialakítása alapvetően meghatározza a végezhető munka minőségét. Ezek az értékek és változásaik képezik a design valóságos történetét. E történet 
egyrészt kötődik az emberiség történetének (technikai, gazdasági, politikai és művészeti) nagy változásaihoz, másrészt önálló, sajátos vonásai vannak, és a használói kultúra által meghatározott forma sajátosságaitól, értékváltozásaitól függ leginkább.

2. A kézmüves termelés évezredein keresztül müködő megbízó-tervező/gyártó-(eladó)-vásárló/felhasználó közötti közvetlen kapcsolatok mélyreható átalakulása, szétszakadása a munkamegosztás előrehaladása révén történt meg alapvetően. A termelés mértékét és milyenségét drámaian megváltoztató gőzüzemü erő- és munkagépek általi gyártás a 18. század végétől mindinkább meghatározó szerepet kapott a szorító társadalmi szükségletek (az egészségügy javulásával bekövetkezett nagymérvű népességgyarapodás), egyszersmind a kiszélesedett vásárlói igények (a lakosság szerkezetváltozása, a megnövekedett városok és a vásárlóerő) kielégítésében. Ezzel együtt a kor új vezető társadalmi ereje, a polgárság (vizuális) identitáskeresése is felgyorsult, mondhatni kényszeressé vált, amelyet viszont megnehezített a korábbi közös világkép, a „külső determináció” és a társadalmi „preformáció” drámai felbomlása [22]. Gondot okozott az új, illetve korábbról ismert anyagok óriási mértékű, új technológiákra alapozott használata mind a termelői, mind a fogyasztói javak körében (a vas, acél és üveg széles körü alkalmazása, a természetes állapotú fa kiváltására irányuló különböző megoldások, a papírmasé és az európai porcelán mellett a kőagyag megjelenése stb.). Mindezt tetézte, hogy az új - polgári-tőkés - társadalom mértékadó erőinek nemcsak kevésbé volt egységes a világképe a korábbinál, de túlnyomó része stabil ízléskultúrát sem hozott magával. A termékdifferenciálás szinte a korai időktől kezdve jellemezte a tervezést, annál is inkább, mivel a kézmüves tradíciók is többfélék voltak a tárgyak gyakorlati (funkcionális) és szellemi (reprezentatív) értékei súlyának különböző társadalmi megítélésétől függően. Ameddig a korszak nagy teoretikusai (David Hume-tól Gottfried Semperig [S2]) mindvégig a hasznosság mellett érveltek elvi alapokon, addig a gyakorlat ennél sokkal sokszínübb volt; a 19. század második negyedétől - a társadalmi problémák mélyülésével - egyre féktelenebbé vált a díszítés, a historizálás. A stíluspluralizmus idején azonban nemcsak különböző stílusok, de különböző tervezési irányzatok is találhatók sokszor azonos terméktípusoknál. Klasszikus példája Josiah Wedgwood keramikus széles körben ismert tevékenysége: használati (vernakuláris) és (klasszicizáló) dísztárgyainak a névtelen mesterek, illetőleg a hírneves szobrász, John Flaxman szépítő tevékenysége általi elkülönítése a különböző társadalmi célok és azokat kifejező kereskedelmi értékek alapján [S3]. A személyes tárgyakon és a belső terek felszerelésén túl - még ha kisebb mértékben is - a munkaeszközök (gőzüzemű erő- és munkagépek) különböző kialakítása úgyszintén jól mutatja a többféle piaci igények egymás mellett élését.

3. A növekvő darabszámú és egyre kaotikusabbá váló gyártmányok az esztétikain túlmutató - és annál súlyosabbnak ítélt - erkölcsi-társadalmi válságot példáztak már a 19. század közepén a kortársak számára is. Ennek leküzdésére különféle javaslatok születtek: a brit morálfilozófusok (John Ruskin, William Morris) nagy hatású mozgalma a gépesítés elutasítását ajánlotta és a középkori katedrálisépítő munka és egyáltalán az ember egészét igénylő kézmüvesmunka értékeinek visszaállítását 
(Arts and Crafts Movement). A gépesítést kiváltó társadalmi-gazdasági kérdésekre természetszerüleg a múltba fordulás nem volt a megfelelő válasz, de e mozgalom a tervezés morális kérdéseinek hangsúlyozásával nagyban hozzájárult a kiürült történeti stílusok eszmei meghaladásához, majd - a Gesamtkunstwerk eszméjét hirdető szecesszió mozgalmán keresztül - végül az ipari termelés és piac spontán elörehaladásával megerősödött funkcionális-vernakuláris tervezési irányzat társadalmi elfogadásához (Sachlichkeit) a 20. század elején [S3]. Ebben az ipari és gazdasági fejlödésben már - a „világ mühelyének” tekintett Nagy-Britannia mellé - felzárkózott Németországnak és az Egyesült Államoknak jutott mindinkább irányító szerep. Különösen a hatékonyságuk révén meggyőző új gyártmányok (író- és varrógép, gépkocsi, fényképező- és filmfelvevőgép stb. és egyáltalán a villanyerő mind általánosabb alkalmazása), valamint a változásokat erősítő, immár az ipari tervezéshez jobban kötődő funkcionális teória (Henry van de Veldétől Hermann Muthesiusig, illetőleg Horatio Greenough-tól Frank Lloyd Wrightig [S2]).

4. A funkcionális tervezési irányzat széles körü társadalmi elfogadásához az első világháború során lejátszódott hatalmas változások járultak meghatározó módon. A Modern Mozgalom, amelynek eredői ugyan az ipari forradalom, illetve a francia forradalom kezdetéig vezethetők vissza, a világháborús pusztítás és a nyomában berobbant új (jobb és szebb) világ építésének - az európai politikai és müvészeti avantgárd által a legerőteljesebben szorgalmazott - igénye nélkül (beleértve az utóbbiak részéről a müvészetek közti határfalak ledöntését) nem így, nem akkor és nem ott született volna meg. Az, hogy az épitö avantgárd (futurizmus, konstruktivizmus) stiláris elemeit felhasználó funkcionális tervezésből hogyan lett funkcionalizmus avagy még világosabban International Style -, csak a háborút vesztett, politikai forradalmakat átélt országok világváltozás-igénylésével együtt érthető meg valóságosan - nem véletlenül nevezte Henry van de Velde a modern designt szociális tervezésnek [S3]. Az új (gazdasági-társadalmi rendet képviselő) világ építésével együtt új vizuális világképet is alkotni kívánó mozgalom végül világméretü hitvallássá vált; a vágyott világrendet mintázó, egyszerre filozofikusan elvont és pragmatikusan, gyártásorientáltan konkrét geometrikus forma- és redukált színvilágával - a színskála alapszíneivel - nagymértékben purifikálta és homogenizálta a vizuálisan létező világot - alapító atyái, így Walter Gropius és mások határozott tiltakozása ellenére - immár funkcionalizmus néven. Kibontakozása (a kezdeti lépéseket megtevő Oroszország mellett) a magas polgári és müszaki kultúrával bíró Németországból és Hollandiából indult el, majd Csehországban és Skandináviában formálódott tovább.

5. A háború veszteseivel szemben, a nyerteseknél kevesen kívántak (azonnali) drámai változásokat, még kevésbé rombolva építő világforradalom árán. Így a tervezéselmélet és tárgyalkotás irányváltásai sem egyféleképpen és egy időben mentek végbe az egyes országokban. A győztes államokban: Franciaországban, NagyBritanniában és az Egyesült Államokban - bár különböző okokkal - érthetően a korábbi kultúra értékeit folytató tervezés (a meglevő, sikeres társadalmi struktúra díszítése) maradt fenn továbbra is (a két európai országnál szolid gyáripari hátterük és hagyományos-szük piaci keresletük miatt elsősorban, míg a közízlésben elmara- 
dottabb amerikainál az Európa korábbi kulturális központját jelentő Párizs divatját követve), az újonnan létesült európai nemzetállamoknál pedig (Csehországtól Baltikumig és Jugoszláviáig) az új identitás megalapozásához használták a - későbbiekben - Art Decónak nevezett (történeti, népi és modern elemekből álló) tervezési divatot a húszas években [S9]. Mellette az évtized fordulójától - a politikai és gazdasági változásokat követve - Európa-szerte megjelentek a funkcionalizmus eszméi és formái is a gazdasági-társadalmi körülmények szerint. Sőt a legfejlettebb, már fogyasztói piaccal bíró Egyesült Államokban létrejött a saját kérdéseikre leginkább választ adó - a modernista Art Decóval rokonítható, a funkcionalizmussal merőben szemben álló - kereskedelemorientált ipari tervezési irányzat: a felgyorsult életformát kifejező áramvonalas styling [S9]. Az egyes országok és gazdaságok ily módon különbözően - sajátosságaik szerint - válaszoltak az őket ért társadalmi-gazdasági kihívásokra.

6. A második világháború előbb csak akadályozta, majd lehetetlenné tette a normális ipari termelést Európában, és a befejezését követően csak idővel - a fizikai és szellemi károk helyreállítása után - kezdődhetett meg újra az építő munka. A háborús károkat nem szenvedő, sőt a háborúban müszakilag és gazdaságilag, továbbá az európai menekültek szellemi kapacitásával erősbödött Egyesült Államok kivétel volt ez alól, ahol megkezdődött az energiatörténet új korszaka - a villamos energia kiváltását ígérö atomenergia drámai debütálásával -, és innen indult a höre lágyuló müanyagok gyors és széles körü elterjedése a mindennapokban. A háborút követő ipari terméktervezésben kezdetben mindenütt a békeévek eredményeinek folytatására törekedtek: Európában leginkább a mélyebb szociális tartalmától megfosztott, gyártásorientált kiterjesztett funkcionalizmus és a kisipari Art Deco, míg az USA-ban a jól bevált, a háborús termelés által felpörgetett ipart és kereskedelmet kiszolgáló - immár újabb európai hatásokkal gazdagodott és finomított - styling szellemében. Csakhogy rövid időn belül mindkettőröl kiderült, hogy folytathatatlanok a korábbi formában: Európában a Bauhaus hagyományait felvállaló ulmi Hochschule für Gestaltung és a körötte található tervezők pályafutása a példa rá, míg az Egyesült Államokban az értékelemzéssel, piackutatással és ergonómiával megerősített industrial design tevékenység terjedése (Henry Dreyfuss, George Nelson). Az amerikai tervezéselmélet (Giediontól Nelsonig és Fitchig terjedő) „dinamikus egyensúly” koncepciójának kimunkálásával új utakat is nyitott a design új értelmezése(i) számára [S2].

7. A Modern Mozgalom kifulladását, annak izmussá beszúkülését és különösképpen az internacionális stílus erkölcsi és formai álságosságát, az alapítók szándéka ellenére terjedő „,szelet-ember”-i létezés (Moholy-Nagy [18], [19]) perspektívátlanságát együtt támadták az igazságkereső társadalmi mozgalmak és hidegen számító piaci erők az ötvenes évek végétől kezdve. A megváltozott történelmi-társadalmi körülmények mellett a „Szép Új Világ” álmának immár látványos bukása: az új háborús gócok és politikai feszültségek újabb megjelenése (koreai, majd vietnami háború, az 1956-os magyarországi és az 1968-as prágai szovjet bevonulás), az értelmetlennek, netán hazugnak bizonyult puritanizmus kudarca a fogyasztói társadalomban, a tömegember-létet megerösítő házgyári lakótelepek, a nyomasztóvá vált 
„konzerv-élet” kialakulása, és ezzel együtt az értékvesztést továbbsegítő „eldobó-kultúra" térhódítása (és még számos tényezö) közösen segítette azokat elő. Mind nagyobb támogatást kaptak a környezetvédőktől, a társadalmi és épített környezetnek a természeti környezet kárára történő gyors gyarapítását ellenző csoportoktól. Az ellenkultúra mozgalmainak kezdetben csupán elutasítást, az ipari társadalomból való teljes vagy részleges kivonulást tartalmazó követelései után rövidesen jelentkeztek a változások céljait és módjait is megfogalmazó tervezői programok, legelőbb az Egyesült Államokban és Nagy-Britanniában, majd Nyugat-Németországban, Franciaországban és az iparilag legingatagabb Olaszországban, valamint Ausztriában is. Egyik részük az érzelmileg elszegényedett, szürke, lélektelen ipari kultúrát elutasító, vagy éppen azt piedesztálra emelő pop kultúrától a neoavantgárd irányzatokig terjedt, és az emocionális értékek (giccs, játékosság, hagyományok és többértelmüség) gazdagabb megjelenését eredményezte a tárgyalkotásban. A velük szembeni rendszerelvüek az embertelenné, formalistává vált tárgyi világot az egyes tárgyak között hiányzó kapcsolatok tisztázásával és tartalmi megerösítésével kívánták racionálisabbá és értelmesebbé, emberibbé tenni - a továbbélő késő modern mellett [S8].

8. A(z újra) kaotikussá lett tárgyi környezetet, amelyet Wend Fischer már a hetvenes években a 19. század végéhez hasonlított, a hetvenes-nyolcvanas évek újabb drámai eseményei tették értelmezhetőbbé - a társadalmi szerepkörök részleges tisztázásával. A nyersanyagválságként indult világgazdasági válság két hulláma után, a kétpólusú világ egyik - keleti - pólusának megroppanásával, az Észak és Dél - gazdag és szegény országok - közötti gazdasági-politikai feszültségek és az egyetemes környezeti károk drámai növekedésével a korszerủ ipari és értékesítési, nem utolsósorban pedig kommunikációs rendszerekbe mindjobban beépülő design egyes irányzatai ugyanakkor funkcionálisan körülhatárolhatóbbá váltak a mértékadó gazdaságokban [S43]. A fogyasztói társadalmakban (a tömegkultúra terjedésével) egyre inkább jellemzővé vált a narratív vizuális kommunikáció (gyakran meghökkentő formai megoldások, súllyal a személyi tárgyak és terek, a közösségi terek felszerelésében), sokszor a visszavágyott kézmüvesség és az ipari gyártás formakaraktere között egyensúlyozva, a munka- és termelőeszközök viszont mindjobban a tudomány és ipar legújabb anyagi és technológiai eredményeinek reprezentánsai, a high-tech által közölve tervezők és gyártók üzeneteit, jelezve használóik társadalmi-gazdasági státusát. Mások viszont - sokszor aszketikus, neo-primitív módon - keresik a túlélés tárgyi alternatíváit. Talán ez sem mindig visszalépés, hanem csak reménykeltő mértéktartás, amikor a világ nagy részének a napi egy marék rizs és a tiszta víz - újabban a tiszta levegő is - hovatovább elérhetetlen vágyálom, a fejlett országokban pedig mind valóságosabbá váló fenyegetés a magas nívójú termeléshez szükségtelen munkaerő és a mindinkább öregedő népesség. Ennek fényében, a tudományos világ naponta felhangzó vészkiáltásai közepette, a papaneki Design for the Real World, a „less aesthetics, more ethic”, a „small is beautiful” program valósággá váltása és kiterjesztése egész környezetünkre valóban sürgető, létfontosságú feladat. Mindezek nyomán az eddigi - többnyire zárt láncú - terméktervezés átalakul új típusú, nyitott végủ termékéletpálya-tervezési folyamattá [S14]. 


\section{EREDMÉNYEK ÉS HASZNOSÍTÁSUK}

1. A gyártmánytervezés korszakain végighaladva láttuk, hogy a használati tárgyakban különbözö célok/funkciók jelennek meg mint értékhordozók, és e funkciók és értékek különböző súllyal érvényesültek és érvényesülnek a különböző korszakokban, helyeken és társadalmakban. Ezek a változások, hangsúlyváltások határozzák meg az ipari tárgyalkotás valóságos, összetett (egyetemes) történetét - az egyes helyek/kultúrák és alkotók, valamint a használt anyagok és technológiák szerint. E változásokat követő, változó szempontú komplex vizsgálat révén a korábban látszólag egymásnak ellentmondó, de legalábbis nehezen értelmezhető tervezési irányzatokból az ipari tárgyalkotás érthető-hasznosítható, sokszólamú története bontakozik ki, amelynek feltárt főbb vonásai immár évtizedek óta cáfolatlanok itthon és külföldön egyaránt. Sőt - látszólag paradox módon - eredménynek tartom, hogy a design összetett alkotótevékenységként való értelmezése és kutatása elörehaladt tevékenységem mellett, nagyrészt tőlem függetlenül, a tudománytörténet számos példájához hasonlóan - a nemzetközi irodalomban, és rokon szellemiségü munkákat eredményezett a designtörténet tudományban. John Heskett [13], Jonathan M. Woodham [31] és mások könyvei ugyanis sokkal inkább megerősítették - egyébként korábban vagy velük egy időben megfogalmazott - föbb téziseimet, mintsem késztettek alapvető korrekciókra. Egyben az is megállapítható, hogy elemzéseik - a design történetének sokirányúságát és részletezettségét illetően - mindmáig nem léptek túl munkámon.

2. A komplex értelmezés alapján sikerült feltárni a történeti változások sajátos mozgatórugóit, mindenekelőtt a design mint professzió kialakulásának hosszú, ellentmondásos folyamatát és összetevőit ( $A$ 'hosszú' 19. század), valamint későbbi nagy korszakainak ( $A$ 'modern' 20. század és $A$ 'modern' után), továbbá azok belső szakaszainak főbb jellemzőit, irányulásait. Ezek a nagy korszakok eltérő értékfelfogásuk alapján különböznek alapvetően egymástól, egyes szakaszaik pedig a termékek formai értékeinek helyi és/vagy időben különböző súlyozása alapján. A nagy korszakokat a nagy történeti változások keretezik: az első elejét az angol ipari forradalom és a francia polgári forradalom, végét az első világháború. Az utóbbi lezárásával indult a második nagy korszak, amelynek befejeződése a második világháborút követően hosszan elhúzódott az egyes országok/kultúrák sajátosságai szerint. A harmadik a század nagy ábrándjának, a társadalmi élet homogenizálhatóságának bukásával egyszersmind a tudományos-technikai forradalom diadalmas elöretörésével, egy élhetőbb - a helyi és egyéni igényeket jobban figyelembe vevő - globális kultúra kialakításának vágyával, a távközlés és -irányítás drámaian új korában, immár a 21 . század feladataként. Ezeket a nagy korszakokat mint „kulturális erőtereket”, a termelés és fogyasztás - beleértve immár a müvészetet is - különböző vonásai jellemzik, és a design megjelenésmódján túl meghatározó alkotóinak a különbözése is. Így - Tomás Maldonado nyomán - a hosszú 19. századét a mesteremberből lett feltaláló, a 20. századot az új típusú művész, ,,a szép, új világ” mérnöke, míg az ezredfordulóét az ökológiai szemléletü koordinátor. Ez egyben visszautal az egyes fő korszakok érték- 
preferenciáira is: az új müszaki megoldások meghatározó erejére a világ alakításában, a hatalmassá lett ipari kultúra formarendje erőszakos megteremtésének és végül a polarizálódott és ökológiailag sértett világ értékzavarának újjászervezése igényére.

3. Vizsgálataim során a kutatás módszertanán is változtatnom kellett, hiszen a többértékű formai minőségek leírására és értelmezésére csak részben voltak alkalmasak a hagyományos müszaki és művészeti történeti leíró eljárások. A mélyebb gazdaság- és társadalomtörténeti elemzések mellett a kulturális antropológia, az információ- és rendszerelmélet megközelítéseit is felhasználtam munkámban. Különösen gyümölcsözőnek bizonyult Bogdan Czekaluknak a vizuális képen túlmutató, a kibernetikából származtatott formaértelmezése, amely új távlatot nyitott a designanalízis számára.

4. Kutatásaim folyamán szükségessé vált a fogalmak újraértelmezése és újabbak bevezetése. Időrendben haladva: 1. a 19. és 20. századi eredmények összehasonlító vizsgálatai nyomán vált fontossá - a német irodalomban Wend Fischer által felvetett - funkcionális és funkcionalista törekvések közti világos tartalmi és formai különbségtétel; 2. a kettös formatervezés - Herbert Lindinger által határozottan képviselt - elméletének a használati forma további értékei szerinti bővítésével formálódott ki egy-egy korszakfogalom és vált lehetségessé a periodizáció; 3. a müvészettörténetben használt stiluspluralizmus fogalmat kiterjesztettem nemcsak stílus szerinti, hanem tervezési irányzatokat is magába foglaló értelmezésre a design történetében; 4. a 19. századi Arts and Crafts Movement és a szecesszió, továbbá az Art Deco szerepét ugyancsak sikerült újraértelmeznem az ipari tárgytervezés szempontjából, az elözőeknek a designelméletre gyakorolt hatása, az utóbbinak formaválasztékot eredményező szerepe alapján; 5. a 20. század valóban új izmusainak és tervezési iskoláinak tárgyalkotó tevékenységére bevezettem az irodalomtörténet és a képzőművészet eseményeire használt építö avantgárd fogalmát, és az ellenkultúra és a posztmodern közötti időszak azon törekvéseire, amelyek már túlléptek a puszta elutasításon és forrásként az építő avantgárdhoz nyúltak vissza, a neoavantgárd megnevezést; 6 . az amerikai termékformálás klasszikus korszakát, majd utána a fogyasztói társadalmak arculatát világszerte meghatározó styling értelmezését is sikerült árnyalnom és pontosítanom az összehasonlító vizsgálatok nyomán; 7. az ugyancsak az amerikai szakirodalomból származó „dinamikus egyensúly” fogalmának használatával és továbbépítésével pedig korunk számára is perspektíva nyílik a tér- és tárgyalkotásban egyaránt.

5. A komplex értelmezés használatára saját publikációim időrendben: a komplex értelmezés alapján készítettem a magyar ipari gyakorlat első felmérését [S21], majd müszaki doktori dolgozatomat és annak könyvváltozatát [S1], melyben már megkíséreltem az értelmezések történeti vizsgálatát is. Ezután az egyetemes elmélettörténet és ipari gyakorlat külön-külön kutatása és publikálása következett [S2, S3]. Utóbbi munkámban már alapoztam a nemzeti termékek vizsgálata során szerzett tapasztalataimra, és ennek során össze is vetettem a különböző eredményeket; ellenőriztem az egyetemes törekvések érvényesülését a hazai körülmények között, és visszavezettem a modifikációkat az egyetemesbe. Így sikerült megtennem az első 
lépéseket - a nemzetközi mintaadók közül különösképpen a brit design hatásvizsgálataival - egy későbbi összehasonlító designtörténet felé is [S8, S10, S11]. Mindezek a kutatásaim vezettek el a tervezéselmélet és termékformálás egészére kiterjedő szintetizáláshoz [S9], majd annak további finomításához [S14].

6. Külön eredményként kiemelném a kelet-közép-európai design 20. századi főbb értékeinek felmérését, mint az egyetemes és a hazai eredmények kettős visszacsatolását. Ebből - a régió és a világ számára méltatlanul ismeretlen - anyagból önálló kötet is született, amelynek legkitűnőbb alkotói és legmarkánsabb müvei már szerepelnek az egyetemes fejlődés történetének újabb feldolgozásaiban [S13]. Fontosnak tartom megemlíteni, hogy ily módon a régió kiemelkedő, de mindeddig nemzetközileg kevéssé ismert tervezői (Zipernowsky Károlytól Walter Zappon és Ladislav Sutnaron át Zdeněk Kovařig és Bozzay Dezsőig) és gyártói (az észt Luther, a magyar Ganz, a cseh Tátra) kerültek be az egyetemes fejlődéstörténetbe. A korábban már nemzetközileg elismertek közül pedig többeknek (például Breuer Marcellnak) sikerült - közép-európai eredményei felkutatásával - új vonásokkal gazdagítani addigi megítélését.

7. A komplex értelmezés alapján látható az is, hogy a design sokban kötődik mind a tudományos, mind a müvészi megismerés sajátosságaihoz, a müszaki, gazdasági, kulturális és társadalmi változásokhoz, ugyanakkor relatív önállósággal bír mindezektől - legközelebbi müfaji rokonságban az építészeti tervezéssel. Társadalmi megítélése sokat változott az idő során: mesterségből lett (alkalmazott, majd az autonómmal egyenértékü) müvészet, később tudomány, s napjainkban a designkultúra egyre inkább az egyetemes nonverbális kommunikáció gyorsan növekvő közegévé válik. Kutatásaim hozadéka lehetséges válasz a Charles Percy Snow által felvetett két kultúra kérdéseire, megerősítve a harmadik kultúrával kapcsolatos angol-amerikai és német vizsgálatokat. Az ipari tárgyak legjobb, érzéki-konkrét formamegoldásai terméknyelven „,beszédesek”, legjobbjai érzelmileg és esztétikailag átélhetők, mégpedig nemcsak elvont müvészeti látványformákként a tudatban, hanem valóságos használatuk során, mindennapi életünk részeként. A gyártmányok ily módon valóban többdimenziós, többértékủ alkotások, „előállítóik és használóik előállítói és használói” is - Diderot és Greenough, Gropius és Eames eszméinek, egyszerübben fogalmazva duális (anyagi és szellemi) emberi létünknek megfelelően.

8. Téziseim és arra épített publikációim főbb gondolatai több évtizede hasznosulnak a hazai felsőoktatásban. Mintegy tucatnyi intézményben megtalálhatók az alapvető tantárgyi kívánalmak között (MOME, korábban MIF majd MIE, BME, Óbudai Egyetem, Nyugat-magyarországi Egyetem, Pécsi Tudományegyetem, Miskolci Egyetem, Kaposvári Egyetem, Budapesti Corvinus Egyetem, ELTE, Nyíregyházi Főiskola, Szolnoki Főiskola). Alapul szolgáltak a pozsonyi és a kolozsvári tervezöképzés történeti oktatásának kiépítéséhez és a lengyel design történetének számbavételéhez is. Könyveimet számos szakterületi kutatásban használták, eredményeim beépültek müszaki és művészeti doktori disszertációkba és az elmúlt évtizedek során végzett több ezer tervezőhallgatóm mindennapi gyakorlatába. Hazai és külföldi irodalmi felhasználásukról - elsősorban is a magyar és kelet-közép-európai eredmé- 
nyek angol-amerikai, német, francia, olasz, lengyel, szlovák, japán és koreai nyelvü publikálása révén - az MTMT-ben található hivatkozási listám tanúskodik bővebben.

9. Dolgozatom ismeretanyaga az oktatás több szintjén túl a szakmai irányításban és a mindennapi gyakorlatban is többféleképpen hasznosítható. Kiindulásul szolgálhat egy megalapozott nemzeti designstratégia kimunkálásához; a tervezett kreatív tudásközpont reális müködési programjának megfogalmazásához éppúgy, mint az ipari támogatás gazdasági és politikai programjaihoz a közelmúltban gyorsan fejlödött országok mintái alapján. A tapasztalatok felhasználásával sor kerülhetne a régóta esedékes hazai múzeumi hálózat - gyüjtő, kutató és kiállító - tevékenységének megnyugtató összehangolására és korszerü müködtetésére, és az újra meg újra előtérbe kerülő országos designgyüjtemény megalapozására.

\section{A CSATLAKOZÓ NEMZETKÖZI SZAKIRODALOM LEGFONTOSABB MÜVEI}

[1] Banham, Reyner: Theory and Design in the First Machine Age. Arch. Press, London 1960.

[2] Braun-Feldweg, Wilhelm: Industrial design heute. Rowohlt, Braunschweig 1965. Magyarul: Ipar és forma. Corvina, Budapest 1978.

[3] Castelnuovo, Enrico et al: History of Industrial Design 1750-1850. Electa, Milan 1990.

[4] Csikszentmihalyi, Michael, Eugene Halton: The meaning of things. Domestic symbols and the self. Cambridge Univ. Press, Cambridge 1981. Magyarul: Tárgyaink tükrében. Az vagy, amit birtokolsz. Libri, Budapest 2011.

[5] Doblin, Jay: One Hundred Great Product Designs. Reinhold, New York 1970.

[6] Dormer, Peter: The Meaning of Modern Design. Towards the Twenty-First Century. Thames and Hudson, London 1990.

[7] Dreyfuss, Henry: Designing for People. Simon and Schuster, New York 1955.

[8] Ferebee, Ann: A History of Design from the Victorian Era to the Present: A Survey of the Modern Style in Architecture, Interior Design, Industrial Design, Graphic Design, Photography. Van Nostrand Reinhold, New York 1970.

[9] Fischer, Wend: Bau, Raum, Gerät. R. Piper, München 1957.

[10] Forty, Adrian: Objects of Desire: Design and Society since 1750. Thames and Hudson, London 1995.

[11] Giedion, Siegfried: Mechanization Takes Command. A Contribution to Anonymous History. Oxford University Press, New York 1948.

[12] Gloag, John: The Missing Technician in Industrial Production. Allen and Unwin Ltd., London 1944.

[13] Heskett, John: Industrial Design. Thames and Hudson, London 1980.

[14] László Ervin: Harmadik évezred: Veszélyek és esélyek. Új Paradigma, Budapest 1998.

[15] Lindinger, Herbert: Design-Geschichte 1-4. Form (BRD) (1965) Nr. 26, 27, $28,30$.

[16] Loewy, Raymond: Never Leave Well Enough Alone. Simon and Schuster, New York 1951.

[17] MacCarthy, Fiona: All Things Bright and Beautiful. Design in Britain 1830 to Today. Allen and Unwin Ltd., London 1972.

[18] Moholy-Nagy Laszlo: Von Material zu Architektur. Albert Langen, München 1929. Magyarul: Az anyagtól az épitészetig. Corvina, Budapest 1975.

[19] Moholy-Nagy Laszlo: Vision in Motion. Paul Theobald, Chicago 1947. Magyarul: Látás mozgásban. Corvina, Budapest 1996. 
[20] Moles, Abraham: Théorie de l'Information et Perception Esthétique. Flammarion, Paris 1958. Magyarul: Információelmélet és esztétikai élmény. Gondolat, Budapest 1973.

[21] Mumford, Lewis: Art and Technics. Columbia Univ. Press, New York, London 1960.

[22] Németh Lajos: A müvészet sorsfordulója. Gondolat, Budapest 1970.

[23] Papanek, Victor: Design for the Real World. Human Ecology and Social Change. Pantheon, New York 1972.

[24] Pevsner, Nikolaus: Pioneers of Modern Movement. From William Morris to Walter Gropius. Faber and Faber, London 1936. Magyarul: A formatervezés úttörői. Gondolat, Budapest 1977.

[25] Pogány Frigyes: Környezetesztétika. Gondolat, Budapest 1975.

[26] Pulos, Arthur J.: American Design Ethic. A History of Industrial Design. MIT., Cambridge (Mass.) 1983.

[27] Read, Herbert: Art and Industry: The Principles of Industrial Design. Studio Vista, London 1934.

[28] Schaefer, Herwin: The Roots of Modern Design. Functional Tradition in the 19th Century. Studio Vista, London, New York 1970.

[29] Schumacher, Ernst F.: Small is Beautiful. Century Hutchinson Publ. Ltd., London 1980. Magyarul: A kicsi szép. Közgazdasági és Jogi Könyvkiadó, Budapest 1991.

[30] Sparke, Penny: Design in Context. Quarto Publishing plc., London 1987.

[31] Woodham, Jonathan M.: Twentieth Century Design. Oxford Univ. Press, Oxford 1997.

\section{A JELÖLT FONTOSABB KÖZLEMÉNYEI A TÉZISEKKEL KAPCSOLATBAN}

\section{KÖNYVEK}

[S1] Az ipari forma története Magyarországon. Akadémiai Kiadó, Budapest 1974. 86 o.

[S2] (szerk. és tanulmányok) Design - Alapelvek. Design Centre, Budapest 1981. 415 o.

[S3] Az ipari forma története. Corvina, Budapest 1982. 209 o.

[S4] A design szerepe a gazdaság új fejlödési pályára történö átállításában a Koreai Köztársaságban. OMFB, Budapest 1990. 65 o.

[S5] Made in Hungary 1885-1914: Az ipari termékformálás kezdetei. Bács-Kiskun Megyei Múzeumok Igazgatósága, Kecskemét 1990. 52 o.

[S6] Made in Hungary: The Best of 150 Years in Industrial Design. Rubik Innovation Fund, Budapest 1992. 155 o.

[S7] Tárgyvilágunk 1896-1996: Iparmüvészettörténeti és -elméleti tanulmányok. Dialóg Campus, Budapest-Pécs 1998. 318 o.

[S8] (ed.) Britain and Hungary (Vol. 1.): Contacts in Architecture and Design during the Nineteenth and Twentieth Century. Hungarian University of Craft and Design, Budapest 1999. 292 o.

[S9] Design: Tervezéselmélet és termékformálás 1750-2000. Dialóg Campus, Budapest-Pécs 2000. 350 o.

[S10] (ed.) Britain and Hungary Vol. 2.: Contacts in Architecture, Design Art and Theory during the Nineteenth and Twentieth Centuries. Hungarian University of Craft and Design, Budapest 2003. 292 o.

[S11] (ed.) Britain and Hungary Vol. 3.: Contacts in Architecture, Design, Art and Theory during the Nineteenth and Twentieth Centuries. Hungarian University of Craft and Design, Budapest 2005. 296 o.

[S12] (szerk. és tanulmányok) Breuer Marcell - Marcel Breuer: Elvek és eredmények. Pro Pannonia, Pécs 2008. 174 o. 
[S13] Muchától Rubikig: Magyarország és Kelet-Közép-Európa 20. századi designtörténetéböl. Ráday Könyvesház, Budapest 2010. 503 o.

[S14] Design: Tervezéselmélet és termékformálás 1750-2010. Ráday Könyvesház, Budapest 2011. 392 o.

\section{KÖNYVRÉSZLETEK}

[S15] Belsőépítészet, Bútor, Colombo, Eames, Kaesz, Thonet. In: Kubinszky Mihály (szerk.): Modern épitészeti lexikon. Müszaki K., Budapest 1978. +4

[S16] Design industriele 1900. In: Sergio Polano (ed.): Budapest 1890-1919. Electa, Milano 1981. $163-180$.

[S17] Der Ungarische Werkbund. In: Dagmar Lüder (Red.): Das Schicksal der Dinge: Beiträge zur Designgeschichte. Kunst, Dresden 1989. 245-256.

[S18] Hungary. In: Lisbeth Hardenberg, Verena Huber, Agneta Liljedahl (eds): Please, be seated! (k.n.), Amsterdam 1991. 48-51.

[S19] Hongrie et 33 article. In: Arlette Barré-Desmond (edit.): Dictionnaire International des Arts Appliqués et du Design. Regard, Paris 1996. +48

[S20] Iparművész és formatervező képzés. In: N. Dvorszky Hedvig (szerk.): A magyar iparművészet az ezredfordulón. Magyar Művészeti Akadémia Alapítvány, Budapest 2003. 21-23.

\section{FOLYÓIRATCIKKEK, KONFERENCIAKÖZLEMÉNYEK}

[S21] Magyar design. Ipari Müvészet (1969) 3. 3-39.

[S22] A design értelmezései és korszakai. Ipari Müvészet (1971) 3. 3-10.

[S23] Ipari forradalom. Ipari Müvészet (1971) 6. 3-10.

[S24] Design a századfordulón. Ipari Müvészet (1972) 5. 11-19.

[S25] Hatások belső térben. Ipari Müvészet (1973) 5. 12-15.

[S26] Bozzay Dezső alkotói útja. Müvészet (1974) 9. 9-13.

[S27] Az ipari müvészettől a rendszertervezésig I. Müvészet (1977) 3. 6-9.

[S28] Az ipari müvészettől a rendszertervezésig II. Müvészet (1977) 4. 42-44.

[S29] Az ipari müvészettől a rendszertervezésig III. Müvészet (1977) 5. 36-39.

[S30] Quality and Industrial Design. Quality and Responsibility (1977) Special Issue 705-707.

[S31] Tiffanytól Moholy-Nagyig: A magyar-amerikai iparmủvészeti és építészeti kapcsolatok történetéböl. Müvészet (1978) 10. 38-43.

[S32] A design útja: a terméktervezéstől a környezettervezésig. Minőség és Megbizhatóság (1979) 2. $150-151$.

[S33] Gio Ponti: Work in Progress. Müvészet (1981) 12. 56-57.

[S34] Design and Styling. Interpressgrafik / Interpress Graphic: Internationale Vierteljahrresschrift für Gebrauchsgrafik (1982) 4. 4-9.

[S35] Értékváltozások az ipari formatervezésben. In: 1. Országos Ipariforma Tervezési Konferencia. Budapest: OMFB IFTI. 1984. (1) 25-35.

[S36] Az ipari forma archiválása I. Ipari Forma (1985) 3. 17-18.

[S37] Az ipari forma archiválása II. Ipari Forma (1985) 4. 16-17.

[S38] Az ipari forma archiválása III. Ipari Forma (1985) 5. 18-20.

[S39] Das handwerkliche und die Serienfertigung (Die allgemenine Charakteristika der universellen Entwicklung und die Praxis der 70-er 80-er Jahre in Ungarn). In: Tradition und Innovation im Kunsthandwerk: Internazionales wissentschaftliches Symposium anlässlich der Quadriennele des Kunsthandwerke Sozialistischer Lander. Erfurt 1986. 59-62. 
[S40] Entwicklungs-probleme und Möglichkeiten des Design unter den wissenschaftlichtechnischen und sozialkulturellen Bedingungen. Wissenschaftliche Zeitschrift der Hochschule für Architektur und Bauwesen Weimar, A Ausgabe 33 (1987) 4. 5. 6. 207-210.

[S41] Eva Zeisel. New Hungarian Quarterly 28 (1987) 107. 197-199.

[S42] A Thousand Buddhas and Top Design. Interpressgrafik / Interpress Graphic: Internationale Vierteljahresschrift für Gebrauchsgrafik (1987) 3. 30-39.

[S43] Developmental Problems and Possibilities in Times of Change. Design Issues (Chicago) 5 (1988) 1. 82-86.

[S44] Az Ipari Mintagyüjtemény terve és szerepe a gyártmánytervezésben. In: 2. Országos Ipariforma Tervezési Konferencia. GTE, Budapest 1989. 309-315.

[S45] Az olasz design a nyolcvanas években. Ipari Forma (1989) 4-5. 1-8.

[S46] Japán design a nyolcvanas években. Müvészet (1990) 37. 8-15.

[S47] Product semantic and global design. DI'JAIN (Seoul) (1991) 4-5. 142-143.

[S48] Nemzetközi tanulságok - hazai feladatok. In: 3. Országos Ipariforma Tervezési Konferencia. GTE, Budapest 1993. 198-204.

[S49] Kotska Rubika. Biuletyn Sztuki Projektowania BSP (2000) 1. 44-45.

[S50] Környezetkultúra és közmorál. In: Köztereink tárgykultúrája és a színes környezet. MKISZ Interdiszciplináris Szakosztály konferenciája. Budapest 2001. 11-14.

[S51] Breuer Marcell angliai évei. Octogon (2002) 2. 44-46.

[S52] Herbert Read magyar kapcsolatai. Ars Hungarica (2003) 2. 63-65.

[S53] Mała rzecz, a cieszy: węgierski dizajn międzywojenny. Autoportret: Pismo o dobrej przestrzeni (Kraków) (2005) 28-31.

[S54] Budapest Tallinn 1900-2000. Magyar-észt kapcsolatok az építészetben és az iparmủvészetben. Régi-Új Magyar Épitömüvészet (2011) 1. 13-14.

[S55] Some characteristics of Košice Modernism in Architecture and Visual Design. In: Košice Modernism: Košice Art in the 1920s. The 2nd Part of 2010-2013 International Project. International conference proceedings. VSG, Košice 2012. 72-83.

\section{BONTA JÁNOSNAK, AZ MTA DOKTORÁNAK OPPONENSI VÉLEMÉNYE}

A szerző hatalmas terjedelmü és súlyú művet készített. Területileg a glóbusz kultúrterületének egészét (Kaliforniától Japánig) áttekintette. E hatalmas területen a népek, országok sokasága mindegyikének önálló eredete, hagyományai, története van és ennek megfelelöen különbözik: munkálkodik, alakítja önmagát és környezetét. A kötet méretei: 400 oldal sürủ szedéssel, jegyzetekkel teli margókkal, a kor nagy gondolkodóinak és korabeli tárgyalkotóinak megfogalmazásaival, a kor teljes valóságának felmutatásával.

Az elmúlt több ezer évben az ember keze munkájával, egyedül vagy csoportosan, viszonylag egyenletesen, ritkán forradalmi megszakításokkal munkálkodott. Ernyei Gyula kötete a korunkat megelőző $250+10$ évet, a mai világot és annak közvetlen előzményeit írja le. Ez telve van újdonságokkal, viharos változásokkal. A termelés gyárakban gépekkel tömegesen történik, ahol a tudomány legújabb ismert eredményeit hasznosítják.

A kor nagy gondolkozói: F. R. Bacon, D. Hume, a felvilágosodás filozófiájának alakjai korábban fektették le a korabeli tudományok és müvészetek alapjait, mintsem 
kibontakozásuk megtörtént volna. Angliában viszonylag korán már fejlett, de bonyolult gépek készültek. Például G. és R. Stephenson „Rocket” gőzmozdonya.

A korabeli viszonyokra jellemző, hogy K. F. Schinkel, a kitünő klasszicista építész, az Altes Museum alkotója, aki tanulmányutakon Manchesterben járt, megállapította, hogy utolsó látogatása óta 400 új fonoda épült, melyeknek otromba tömegei a templomtornyokat eltakarják. Vélekedése hasonló a magyar lakosságéhoz a panel lakóházak tömegeiről. Ez a példa a túlcsordult ipari forradalom két arcára mutat, ami óriási termelésnövekedést eredményezett, ugyanakkor a müvészet ellen hatott.

A J. Paxton által épített „Kristálypalota” (1852) üveg-vas szerkezetü terében a kortársak által elítélt, díszített gépek álltak.

Néhány sor W. Morristól: ,„a gépi termelékenység mögött a női és gyermekmunka kizsákmányolása állott..., az emberi élet számára alig elviselhető városrészek nyomora”. W. Morris szerint ,a világ választhat, megtartani vagy feladni akarja-e a müvészetet”. A preraffaeliták éles harcban álltak a gépesítés híveivel, a racionalistákkal, a funkcionalistákkal. Morris által inspirált közismert alkotás a Ph. Webb által tervezett Red House, ami a természeti környezet részeként hat.

Az ipari fejlödésben Nagy-Britanniát elsőként Franciaország követte a kontinensen. A 19. század müszaki és gazdasági életének fejlődésére az angol ipari forradalom volt hatással, politikáját és ideológiáját azonban föként a franciák alakították ki. A francia ideológusok legnagyobb szabású tudományos vállalkozása és teljesítménye az Enciklopédia, avagy a tudomány, a müvészetek és a mesterségek elméleti szótára volt (1751-1772).

Nagy-Britanniában Ruskin és Morris hatására a romantikus, érzelmes természet közeli irányzat élvezett elsőbbséget az ipari-technikai fejlődéssel szemben. D. Diderot az Enciklopédia föszerkesztője világosan felismerte az ipar jelentőségét. A „,Müvészet" szócikket az Enciklopédiában elsősorban a mechanikai művészetek leírásának szentelte.

A francia forradalmi építészek Ledoux, Boullée és társaik a puritán funkcionális alkotásokkal hirdették a funkciót hangsúlyozó autonóm tervezési elveiket. A francia mérnöki szerkesztés diadalát hirdeti az Eiffel-torony.

Ernyey Gyula müvének legnagyobb erénye, hogy a gyártott világ precíz leírásán túllépve a kor humán világát is bemutatja. Az ember által alkotott tárgyi világ: eszközök, gépek, berendezések segítségével nemcsak gyakorlati feladatot old meg, hanem ,....magát nemcsak - mint a tudatban-intellektuálisan, hanem dolgozva-tevékenyen, valóban megkettőzi és ennélfogva önmagát egy általa teremtett világban szemléli" (Marx).

A mai Németország területén 30-40 kisebb, nagyobb területi egység helyezkedett el; a széttagoltság okozta lemaradását. Amikor a Német Szövetség létrejött, viharos fellendülés következett be. Elsősorban a filozófia terén. A német filozófia a 19. század elején a klasszikus európai filozófiai gondolkodás csúcsára jutott el (Kant, Hegel stb.). Figyelemreméltó a korszerü porcelánedények, -készletek célszerüsége és vonalainak szépsége. Híressé vált ez időben a Thonet-bútor, amely Ausztriában és Magyarországon is széles körben elterjedt. 
A modernitás csírái az Amerikai Egyesült Államokban az ún. „Chicagói Iskola” alkotásaiban jelentkeztek. Legjelentősebb építészük F. L. Wright családi házainak helyiségeit központi kémény és kandalló köré csoportosította. Másik nagy alkotójuk L. Sullivan, híres mủve a Carson, Pirie and Scott áruház. Homlokzatán széles hármas ablakokkal, a bejáratnál dús szecessziós díszítéssel. Az amerikai gyártást általában a praktikumra való törekvés jellemzi.

A modern építészet ébredése Európában először Hollandiában érhető tetten. Alapítója Theo van Doesburg festő, író, tipográfus, formatervező. Zseniális társa a festő Piet Mondrian absztrakt festészetét a környezetalakítás ügyének szentelte. Gerrit Thomas Rietveld a kísérletező teoretikusok eszméinek realizálója. Híres müve a Schröder-ház. Az épület olyan, mint egy, a térbe átment Mondrian-festmény: könynyed, kártyavárszerúen lebegő. A belső a mindenkori igényeknek megfelelően változtatható helyzetü válaszfalakkal, szabadon berendezhető. Rietveld másik fő müve a „piros-kék szék”. Kereszteződési pontjain az egyes elemek önállóságukat megtartva túlszaladnak egymáson. Ezáltal behatolnak a térbe. Megemlítendő Huszár Vilmos magyar származású festő, grafikus, lakberendező, a mozgalom egyik alapítója. A Stijl látomásában a tér, amelyben élünk és tevékenykedünk, háromdimenziós absztrakt hálózatot alkot, amelyben különböző méretü lemezek és hasábok szabadon lebegnek.

Röviden a filozófiai háttérről. Mondrian barátja volt Schoenmaekers, a teozófia mủvelöje, aki eszméit a nagy holland filozófusig, Spinozáig vezeti vissza. Tanításainak lényege: egész környezetünket, a természetet és az ember által készített tárgyakat áthatja a lélek. Hasonló gondolatot fejez ki Rudolf Steiner is, akit Makovecz Imre így idéz: ,a ház lény”.

Az elmúlt 250 évben a térről és az időről való felfogásunk a fizika és a matematika felfedezései után (Einstein relativitáselmélete) átalakult. Ezzel együtt az építészet és a design tere is megváltozott. Az építészeti teret áthatja az idő (S. Giedion: Space, Time \& Architecture c. kötete). Ernyei Gyula nagyszerü könyvének egyetlen hiányossága az építészet, illetve design térlátásának, ill. térszervezésének viszonylagos mellőzése.

Ebben a modern térben mozognak a Stijl alkotásai is. Nem hagyhatjuk említés nélkül L. Mies van der Rohe müveit sem: a Barcelona Pavilont és a Tugendhat-házat. Az elsőnél párhuzamos, szabadon lebegő márványfalak terelik a teret, majd áttörve az üvegfalat egy medencét kerítenek be. A másodiknál az egy térben elhelyezett különböző funkciójú térelemeket a bútorzat és lebegő falelemek motiválják. A Tugendhatház egy terétől egyenes út vezet az USA-ban szabványossá vált irodaháztípushoz, amelynél a mellékhelyiségek központi magját üres egytér fogja körbe.

Az első világháború után forrongó Oroszország építészei fantáziagazdag, absztrakt, sőt gépszerü müveket is alkottak, mozgó alkatrészekkel demonstráló épületeket is. Legismertebb közülük Vladimir Tatlin Harmadik Internacionálé Emlekmüve (1920), ami két egymásba fonódó rácsszerkezetü csigavonal. Belsejükben négy üveghasáb, amelyek meghatározott időszakokban változó sebességgel forogtak volna. Másik fantasztikus terv El Liszickij Felhővasalója (1924). A cél az amerikai 
felhőkarcolók orosz változatának megalkotása, ezzel együtt a Moszkva belvárosát övező körút csomópontjain kapubejáratok kialakítása. Az utópista fantaszták közül alighanem a legtehetségesebb Ivan Leonyidov ismert terve, a Lenin Intézet (1927). Üvegezett toronyból kábeleken üveggömb függ, amelyben nagy előadóterem kapott helyet. Kazimir Malevics szuprematista festészeti iskolájából jöttek elő Liszickij és Leonyidov is. Malevics hasonló szerepet játszott az oroszok között, mint Mondrian a Stijlben. A nagyméretü szimbolikus és agitatív célú struktúrákon kívül Tatlin és Rodcsenko „Produktivistákkent” is dolgoztak. Könnyü, összecsukható bútorokat, tartós munkaruhákat is terveztek. A,„nomád” indíttatás hatott az európai építészekre, a Bauhausra, Miesre, Le Corbusier-re. Breuer csőszéke, a híres Vaszilij-szék egy időben keletkezett a moszkvai iskolában készített csővászon székkel (1926). Az akkori avantgárdok szoros kapcsolatára utal Rodcsenko és Moholy-Nagy levelezése is.

A szimbolikus nagystruktúrák és a napi használati épületek között rengeteg érdemes középület is készült, mint Konstantin Melnyikov Ruszakov munkás kultúrháza (1927-1928). Belső elrendezése a külsőben hüségesen nyomon követhető. Nyers, egyszerü funkcionalista építmény. Alexander és Vlagyimir Vesznyin Pravdaszékháza (1923) üveghasáb gépi elemekkel: kereken forgó hírközlővel, időkijelzővel, külső liftekkel. Példaértékü Konsztantyin Melnyikov (1890-1974) piaca elöregyártható és szétszedhető elemekböl.

Utoljára a legnagyobb téma a város- és lakásépítés. Az idő előrehaladásával az álmok, fantáziaképek helyébe egyre inkább praktikus igények és társadalmi feladatok léptek. Ezzel párhuzamosan az éles stíluskísérletek mindinkább egyszerüsödtek, praktikus megoldásokba mentek át. Az álmok körébe sorolható több városépítési terv, mint Leonyidov Magnyitogorszk terve (1930), ami 32 kilométer hosszan, 6 sávban kapcsolta össze a mezőgazdasági kommunát az iparteleppel. A lakásépítés Moisei Ginsburg vezetésével „kollektív házak” tipizálásával indult. A középfolyosós lakóházak kislakásai közvetlenül kapcsolódtak az éttermet, tornatermet és óvodát tartalmazó tetökertes épülethez. A kísérlet nem vált be (Nakomfin lakóház, 1929). Az említett és a további kísérleteket az illetékesek és a lakosság is elutasította. Helyettük Ernst May frankfurti építészt és csoportját hívták meg Magnyitogorszk városának építésére, közöttük volt Weiner Tibor magyar építesz is. Az eredmény: egyforma szürke épületsávok. Íme az álmok, fantáziaképek a fejlődés folyamán egyöntetü Bauhaus-házakká egyszerüsödtek. Az utolsó modern Bauhaus-lakóház (1934) Ginsburg keze nyomát viseli. 1932-ben a Párt átvette az építés irányítását. Feloszlatta az egymással vitázó avantgárd iskolákat, és megbízta a még élö akadémikusokat a „munkásosztály igényeinek és ízlésének megfelelőbb építészet kialakítására”.

A Bauhaus volt kétségkívül a modern európai építészet legjelentősebb központja. Walter Gropius vezetésével itt alakultak ki az ún. „Bauhaus-stílus” általános elvei. Ezek szerint: a formának közvetlenül meg kell felelnie a funkciónak, az anyagnak és a szerkezetnek. A Bauhaus-építészek elhárítottak maguktól minden díszítési, kompozíciós eljárást, azaz stílust. Legjelentősebb alkotásuk a dessaui iskolaépület (1925-1926). 
Vezető tervezője maga Gropius. Betonból, üvegböl készült, logikusan tagolt építmény. A konstruktivizmushoz közeli, puritán funkcionalizmus példaképe. A Bauhaus azáltal vált központi jelentőségüvé, hogy Európa minden tájáról tehetséges fiatalok rengetege áramlott felé, akik részben tanárai, mesterei, másrészt tanítványai, segédei lettek. Elsősorban az építészmesterekről szólnék. A Bauhaus alapítója, arcának kialakítója W. Gropius. Követője az igazgatói poszton Hennes Meyer, utolsó vezetője, aki kénytelen volt a küzdelmet a Bauhaus-iskoláért feladni L. Mies van der Rohe. Leghüségesebb segítői, Moholy-Nagy László, Breuer Marcell Gropiusszal emigráltak az USA-ba. Említendők még Forbat Alfred (Fred), Weininger András építészek, Kállai Ernő művészeti író, Papp Gyula fémmüves és még sokan mások.

Sokan rövidebb-hosszabb időre ellátogattak a Bauhausba. A nevesebb látogatók közül megemlítem Doesburgot, aki be akart volna olvadni az iskola testületébe. De általunk nem ismert okokból nem fogadták be. Ezért önálló tanfolyamot nyitott, amelyet sokan látogattak. Közöttük Molnar Farkas (1897-1945) építész, a két világháború közötti modern magyar avantgárd építészet vezető egyénisége. Villaépületeinek könnyedsége, áttetszősége, a berendezés mozgathatósága félreérthetetlenül Stijlhatásról árulkodik. Például a Harangvirág utcai villa görgőkön mozgatható válaszfalakkal kilencféle módon rendezhető be. A közvélekedés kizárólag Bauhaus-stílust emleget. Ez tévedés. A Stijl legalább ilyen hatást gyakorolt a modern magyar építészetre.

Néhány gondolat az építészet lényegéröl. Két zseniális építesz Alvar Aalto és Le Corbusier. Aalvar Alto szembekerült Mies-szel, aki a tipizált funkciók optimális megoldását kereste meg és használta fel sokszorosan. Aalto vele szemben a feltételek végtelen változatosságára, az ember pszichológiai, biológiai sokféleségére figyelt. Aalto természetes építészetet művelt. A fa görbületei, a tópartok ívelése, a szélfútta homok rajzolata előképei a Viipuri-könyvtár mennyezetének (1927-1935), a Villa Mirea (1937-1938) hajlított körvonalainak, bútorainak, üvegpoharainak. A falécekkel burkolt felületek hatottak a II. világháború utáni magyar modernekre is: Mémosz székház tanácsterme (Gádoros, Perényi, Preisich, Szrogh), kultúrház Hódmezővásárhelyen (Janáky, Jánossy).

Le Corbusier a kor legjelentősebb építésze. Első évtizedei inkább az utazás, a tanulás, a tájékozódás időszakai. Ekkor fogalmazza meg alapvető építészeti meglátásait, Vers une Architecture c. kötetét (1923), a vasbeton vázszerkezet konzekvenciáit, híressé vált Öt pontjában a Citrohan-ház koncepcióját, amit városépítési terveiben használt fel (Ville Contemporraine, 1922, Plan Voisin, 1925). Kis irodát vezet. A magyarok közül ifj. Dávid Károly és Wanner János dolgoztak nála. Legmonumentálisabb épületterve a Szovjetek palotája (1951). Parabolaívről kábeleken függ az óriási ülésterem. Lélegzetelállító alkotás lett volna. A II. világháború után bontakozott ki agyagszerủ plasztikus mủvészete, amelyik csúcspontját a kézzel formáltnak ható, az őskoritól a máig ható világunk teljességét idéző Notre Dame du Haut kápolnával (Ronchamp, 1950-1954) érte el. 
Le Corbusier elsősorban művész volt, nem tudós, aki az építészet lényegét így fogalmazta meg: ,,az építészet nem más, mint plasztikus formák müvészi nagyvonalú és korrekt játéka a fényben”. A két világháború közötti időszakból legmegragadóbb a Villa Savoye, lábakon álló, fehér, lapos kubus, amelybe egy negatív dobozt vájt bele (1929-1931). Kötetében ezeket írja: „kőből, fából, cementből házakat, palotákat alkotunk. Ez építkezés. A leleményes ész munkálkodik... De hirtelen valami szíven üt, valami jól esik, boldognak érzem magam, azt mondom: szép. Ez építészet. Ez már müvészet."

A müvészeteknek már a preraffaeliták és a felvilágosodottak idejében is kettős arca volt, ami a 20. században a modern eszme és formavilág széteséséhez vezetett. A lakosság súlyosan bírálta a gépesített, tömegesen gyártott és uniformalizált tárgyakat, a „kockaházat, panel épületeket”. A szakma posztmodernről, neomodernről, dekonstrukcióról beszél. A modern világ, amelyért egykor lelkesedtek, szétesőben van. Új világ kezdődött.

\section{SISA JÓZSEFNEK, AZ MTA DOKTORÁNAK OPPONENSI VÉLEMÉNYE}

A müvészettörténet sajátos területe a design. Nem lenne szerencsés határterületet mondani, mivel az új müvészettörténet-írás egyre inkább tekint ki eddig feltáratlan irányokba, illetve alkalmaz kevéssé szokványos módszereket, s ezáltal von be egyre szélesebb körből jelenségeket vizsgálatának tárgyai közé. Nem sok idő kell hozzá, hogy az eredetileg periferiálisnak, interdiszciplinárisnak tekintett területek vagy megközelítések a mainstream kategóriájába kerüljenek. Eredendöen még az iparmüvészet sem tartozott a müvészettörténeti tanulmányok fö sodrába, és ma már régóta teljes jogú ága a müvészettörténetnek. Jelen munkájában, akadémiai doktori disszertációként benyújtott könyvében Ernyey Gyula is korábban szokatlan távlatok felé tekint vizsgálódásában, amivel nem kevés eredeti gondolat és megközelítési mód kibontására teremt alkalmat.

A jelölt már régóta foglalkozik választott témájával, a design problematikájával. Nyugodtan mondhatjuk, hogy több évtizede folyamatosan bővíti és csiszolja ismereteit és téziseit, illetve teszi ezeket közkinccsé. Ilyen témájú könyveinek sorát $A z$ ipari forma története Magyarországon c. munka nyitotta meg, amely a patinás Müvészettörténeti Füzetek sorozatban jelent meg 1974-ben. Ezen úttörő jellegü és immár klasszikusnak számító müvet követte 1983-ban Az ipari forma története a Corvina Kiadó gondozásában. Ez után jelent meg a Made in Hungary. The Best of 150 Years in Industrial Design 1993-ban, A Tágyvilágunk 1896-1996 c. kötet 1998ban, a Muchától Rubikig: Magyarország és Kelet-Közép-Európa 20. századi designtörténetéböl c. könyv 2010-ben. A felsoroltak mellett 1999 és 2005 között a jelölt sok szerzőtárs-szakembert megmozgatva - szerkesztőként és szerzőként 3 kötetben foglalta össze a brit-magyar müvészeti kapcsolatokat, jelentős szerepet szentelve a 
design problematikájának. Vagyis a jelen munka egy eredményes szakmai pályafutás egészének egyfajta összefoglalása, egy kiforrott tematika summázata.

Mielőtt a részletesebb elemzésre rátérnék, tanulságos megvizsgálni a felsorolt címeket terminológia szempontjából. A terminusoknak ugyanis jelen esetben tartalmi jelentőségük van. Az első még az ,ipari forma” megjelölést használja. Csak az 1993as munkában tünik fel a design szó, igaz, maga a cím - és a kötet - is angol nyelvü. Utóbb már a magyar könyv címében, illetve a most tárgyalt munka szóhasználatában is a design szó szerepel. Ez az angol terminus ugyanis átfogóbb jellegü, mint az ipari formatervezés, általában formatervezést, a tárgyakkal való alkotó folyamatot jelenti, és mint ilyen, az iparmüvészetet, de legalábbis annak széles területét ugyancsak magában foglalja. A fogalom egy, eredendően magyar szóval valószínüleg nem is leírható. A szóválasztással a szerző eleve jelzi, hogy vizsgálata széles horizontú, egyúttal viszont igazodását mutatja a nemzetközi, az angol terminust preferáló trendhez.

Ha terminológiáról, illetve a magyar terminológiáról beszélünk, érdemes néhány szót ejteni a helyesírásáról is. A „design” szó már oly mértékben meghonosodott a nyelvünkben, hogy magyar fonetikus helyesírása is létezik, sőt ma már talán elterjedtebb, mint az eredeti angol helyesírás. Az általános tendenciákat figyelembe véve valószínünek tünik, hogy idővel a magyar fonetikus helyesírás lesz a sztenderd és az egyeduralkodó, elég, ha analógiaként például az eredeti francia „renaissance” magyar „reneszánsz”-szá formálására gondolunk. De az is lehetséges, hogy Ernyey Gyula azért maradt meg az angol helyesírás mellett, mert ezzel akarta hangsúlyozni munkája történeti megközelítését és nemzetközi tematikáját, szemben a magyar helyesírású változattal, amelyik egyelőre talán inkább a kortárs formatervezéssel azonosítható.

A kötet jól áttekinthető és logikusan strukturált: a történettudományi szakmunkák bevett rendszerét követve kronologikus felépítésű. Kiindulási pontja az ipari forradalom, amely végeredményben az eredője mindannak, amiről e kötet szól. Itt érthető módon az angol fejlemények kapnak nagy hangsúlyt. A következö súlypont a 19/20. század fordulója. Külön fejezetet kap - a kötetben szereplö terminust idézve - a „modern”, vagyis a 20. század két világháború közötti időszaka. Az, hogy a „modern" a müvészettörténetben nem a mindenkori kortársat jelöli, hanem egy bizonyos, sajátos jegyekkel meghatározható és évszámokkal leírható korszakot, immár elfogadott gyakorlat. Ezzel cseng egybe a „A 'modern' után” címü fejezet, amely a hatvanas évektöl az ezredfordulóig követi a design történetét.

A szerző a design fogalmát az emberi kultúra és alkotás széles spektrumára terjeszti ki, amely elsősorban az ipari termelés valamilyen formájával függ össze. Ez értelemszerüen magában foglalja a hagyományos tárgykultúra - mai fogalmaink szerint az iparművészet - egyes ágainak alkotásait, mint ahogy az ipar által létrehozott, de a mủvészet kategóriába szorosan nem sorolható termékeket, sőt ezen felül a müszaki alkotásokat is. A szerző minden korszakban tárgyalja a különféle edényeket és bútorokat; ezek a vizsgálódásai főszereplöi közé tartoznak. Egyes esetekben kitér a bútorokat magában foglaló nagyobb együttesekre, az enteriörökre is, bár ilyen 
irányban tovább bővíthette volna a bemutatott anyagot. De amint a történelem során feltünnek, bevonja a vizsgálatba az emberi környezetben megjelenő legkülönfélébb gépeket, mint a varrógép, az írógép, a rádió, a fridzsider, a televíziókészülék. Végig lehet követni a formatervezés modern emberi léttel kapcsolatos külön terrénumát alkotó jármủveket is, legyenek azok személyautók, buszok vagy vonatok. A részletesebb elemzés jóvoltából a széles mezőnyből saját jogon, de a részletesebb elemzés okán is kiemelkednek egyes, immár ikonikusnak minősíthető tárgyak - mert már ebben a müfajban is léteznek ilyenek -, mint a Colt ismétlőpisztoly, a Singer varrógép, a Thonet-szék, a piros londoni telefonfülke vagy a bogárhátú Volkswagen. Ezen rövid és némileg önkényes tételszerü válogatással jelzésszerüen érzékeltetni szerettük volna, milyen széles a disszertációban tárgyalt objektumok spektruma.

A téma specifikumából fakadóan a szerző újszerü szempontokat is górcső alá vesz; ilyen pl. az ipari folyamatok, illetve az anyagok természetéböl és a technikából eredeztethető jelenségek. A szóban forgó munka azonban nem pusztán az ipari fejlödés technikai lépéseit és vívmányait, a kapcsolódó objektumcsoportokat és azok esztétikumát tárgyalja. Szemlélete ennél átfogóbb, az interpretálási módszerek igen széles tárházával operál. Igénybe veszi a tágabb történeti, filozófiai és eszmetörténeti szempontokat, sőt felhasználja a kulturális antropológia módszereit is. A szerző ugyanis a szorosan vett tárgykultúrán kívül mindvégig figyelemmel követi a társadalmi elméleti hátteret, és ezek együttes vizsgálatát végzi el, illetve így vonja le következtetéseit. Így pl. az angol ipari forradalom kapcsán a kortárs természetfilozófia és közgazdaságtan főbb képviselői, illetve mozzanatai is górcső alá kerülnek. A 19. századi fejleményeknél a világkiállítások közvetítő és inspiráló szerepe kerül megfelelő világításba. Az először Amerikában felfutó, majd világjelenségként definiálható tömegtermelés hatása, a vele kapcsolatos új fejlemények és dilemmák, és az arra történő reakció szintén a tárgyalás részét képezi, mint ahogy az életforma-változás hullámverései sem kerülték el figyelmét. De nem kerülik el a szerző figyelmét a társadalmi-lélektani mechanizmusok, a reklám szerepe és hatása - ez egyébként épp a designnak egyik megjelenési és alkalmazási formája -, vagy a változó életformával összefüggő kérdések. Az ideológia mint föszereplő a fiatal Szovjetunió kapcsán kerül előtérbe. Talán megérte volna a nemzeti szocializmus hasonló jelenségeit is megvizsgálni - a korábban tabuként került kérdéskör ma már legitim kutatási témának számít.

A doktori munkában a történeti és kronologikus tárgyalás általában logikus, arányos. Viszont van egy terület, melyet a szerző nem, vagy alig érint, illetve amikor futólag szót ejt róla, akkor is inkább negatív konnotációval. A 19. század második feléről, a historizmusról van szó. Ennek a kornak is megvolt a bútorművészete és tárgykultúrája, és általában a designja, még ha erősen el is tért az ipari forradalom és a klasszicizmus, valamint a századforduló és az azt követő korszak felfogásától és formavilágától. A történeti korokhoz való intenzívebb viszonyulás, a régi előképek erősebb figyelembevétele kétségtelenül másfajta tárgyakat hozott létre, mint azelőtt vagy azután, interpretálásuk szintén más hozzáállást igényel. Ezekről a szerző meglehetősen sommásan ítélkezik, ilyen megjegyzéseket téve, mint „a tárgyi környezet 
alakításának ellentmondásosabbá válása, hanyatlása” (47. old.), vagy „pszeudo-építészet és pszeudo-design" (86. old.). Kétségtelen, hogy még nem jutott nyugvópontra, de a historizmust és produktumait lehetett volna árnyaltabban és differenciáltabban is megközelíteni, különösen annak fényében, hogy a historizmus rehabilitálása folyamatban van, illetve részben megtörtént. A szerző lényegében teleologikus szemlélettel áll a historizmus problematikájához, amelynek a lényege, hogy a fejlödés funkcionális alapokból kiindulva halad a modernizmus és a kortárs design felé. Ha ezt a fajta logikát mint módszert elvileg el is lehet fogadni, fel szeretném hívni a figyelmet, hogy a historizmusnak is megvoltak azok a történelmi asszociációkon túli aspektusai, amelyek a szorosan vett designtörténeti szemlélődésbe beletartoznak, és a szerző által választott megközelítéssel is tárgyalhatók lettek volna. Ilyen egyebek mellett az ornamentika. Az ornamentika mint önálló tényező a 19. század közepén került a közgondolkodás fókuszába, illetve vált az építészet, a társmüvészetek és a mai fogalmaink szerinti iparművészet egyik meghatározó tényezőjévé. Egy másik vizsgálati irány lehetett volna a historizmus korában oly fontos szerepet játszó komfort jelensége, amelynek megvolt a lakberendezésben, a formatervezésben, az anyaghasználatban is a hozadéka. Ebbe a körbe tartozik az ülöbútorok formai és típusbéli változatossága, a bútorok rugózásának kifejlesztése, a textíliák bőséges alkalmazása, a meleg, sötét színek preferálása. De ide tartoznak a komfort szolgálatában álló technikai eszközök, a modern épületgépészet megjelenése és vívmányainak alkalmazása, ami egyébként egy további szempont, a higiénia problematikájának vizsgálatára is adhat alkalmat.

Egy másik megjegyzés a magyar alkotókra vonatkozik. A szerző meglepően keveset foglalkozik a hazai tervezők működésével és alkotásaival, még akkor is, amikor azok az egyetemes fejlődés kontextusában is számottevőnek tünnének. A magyar szecesszió például létrehozott olyan alkotásokat, amelyek helyet kaphattak volna a kötetben. Ha magyarokról vagy magyar alkotásokról van szó, figyelme elsősorban azokra irányul, akik a nemzetközi színtéren is feltüntek. Ilyenek a Bauhaus magyar szereplői vagy a Ganz-gyár villanyvasútja, vagy - hogy a közelmúltból idézzek - a Rubik-kocka. A szerző feltehetően abból indult ki, hogy a magyar fejlődést más kötetekben már megírta, és azokat nem akarja itt részleteiben megismételni.

A jelen kötet széles bázison nyugszik. Ennek része Ernyey Gyula saját, primer kutatása, melynek eredményeit a korábbi munkáiban tette közzé, és amelyeket továbbfejlesztve beépített mostani munkájába. A kötet alapját képezi továbbá az egyetemes szakirodalom, melyet a szerző régóta követ, és amelynek eredményei egyébként saját kutatására is inspiráló erővel hatottak. A hazai és a nemzetközi szakirodalom ismerete és alkotó felhasználása tette lehetővé, hogy a nagy szintézis mint új és önálló minőség létrejöhessen. Összességében egy rendkívül ötletgazdag, ugyanakkor hatalmas tényanyagot felölelö, önálló munka jött létre. Külön kiemelést kíván a könyv stílusa. Ernyey mindig törekszik arra, hogy egyrészt ökonomikusan és tömören fogalmazzon, felesleges fejtegetésekbe, ismétlésekbe ne bocsátkozzon. Ugyanakkor amit leír, az sodró lendületű, találóan megformázott, lényegre törö, így a kötet jóformán olvastatja magát. 
A munka - a tartalmán kívül - a tudományos értekezés formai kritériumainak is eleget tesz: részletes jegyzetapparátus kíséri, és terjedelmes, kategóriákra tagolt bibliográfia zárja le. A szokásos szakirodalmi jellegü apparátuson kívül a végén „tárgyi anyag" címen szerepel benne egy hosszú jegyzék is, amely felsorolja azon gyüjteményeket, múzeumokat és fotóarchívumokat, amelyek anyagát a munkájához tanulmányozta, illetve felhasználta. A kötet legvégén mutató segíti a 380 oldalas munkában az eligazodást.

A szövegen kívül kiemelésre kívánkozik még a képanyag. A sok száznyi kép böségesen és a kellő helyen, a megfelelő helyre tördelve szerepel a kötetben. Többnyire kisméretủek, nem akarják megjelenésükkel és terjedelmükkel elnyomni a szöveget. Amely alkotásokat vagy tárgyakat a szerző fontosnak talált, blokkokba gyüjtve, színes ábra formájában szerepelteti. Aki hasonló terjedelmü könyvet már írt vagy szerkesztett, az tudja, hogy a megfelelő képek összegyüjtése, beszerzése, a köteten belül a szöveggel történő összehangolása igen komoly feladat. A szöveges rész megkomponálásán túl a szerző, illetve nyilván a szerző instrukcióit követve a kötet tervezője ezt is kiválóan megoldotta.

A fentiek alapján javaslom a Tisztelt Bíráló Bizottságnak a mü nyilvános vitára bocsátását, illetve Ernyey Gyula számára az akadémiai doktori cím odaítélését.

\section{SIMON MARIANNAK, A MÜSZAKI TUDOMÁNY KANDIDÁTUSÁNAK OPPONENSI VÉLEMÉNYE}

Az MTA Doktori Szabályzata lehetővé teszi, hogy doktori műként egy három évnél nem régebben kiadott könyv is benyújtható legyen. A könyv - szóljon az bármely közönséghez is - és a szakmai tudományos közösség számára készült értekezés persze két különböző müfaj, ami többnyire nehezíti a könyvnek értekezésként való megítélését, az opponens dolgát. Ernyey Gyula könyvének a megcélzott közönsége elég széles, legalábbis a kiadói szerkesztőnek a hátsó borítón olvasható ajánlása szerint. A könyv „remélhetőleg a felsőfokú tervezőművész és mérnökképzés kézikönyve lesz... a tervezői pályára készülők elengedhetetlen olvasmánya, sőt a diplomás tervezők számára alapvető szakkönyv. Nem nélkülözhetik a reklámügynökségek, az arculattervezéssel foglalkozó designstúdiók és a nyomtatott és elektronikus sajtó munkatársai sem, és élvezetes mü a mindennapi élet tárgyvilága iránt érdeklődő olvasók szélesebb köre számára is.” A szakemberektől az egyetemistákon át a szélesebb érdeklődő közönséget is felölelő olvasói kör megcélzását talán azért merte felvállalni a kiadó Ráday Könyvesház, mert a munka valóban ambiciózus, a design teljes történetét kívánja feldolgozni és bemutatni, ami hazai téren egyedülálló vállalkozás.

A vállalkozás tehát egyedülálló, különösen, hogy a szerző az ipari forma történetét nemcsak a gyakorlat, hanem az elmélet felől is közelíti, a történetet pedig a feltételezett kezdetektől egészen napjainkig követi, az így átfogott idő 260 év. Egy időben és témájában ennyire kiterjedt vizsgálat sok munkát és érlelést, hosszú időt kíván, 
akár egy teljes életmüvet is, ahogy az esetünkben is történt. Ernyey Gyula 1972-ben, egyetemi doktori értekezésében foglalta össze elöször a témában gyüjtött ismereteit. Azóta számos könyvben és tanulmányban bővítette az anyagot, vizsgálva a hazai és a nemzetközi szcénát, a gyakorlatot és az elméletet, közben fokozatosan haladva egyrészt visszafelé az időben, keresve a gyökereket, másrészt haladva elöre, követve és rögzítve az újabb eseményeket.

A doktori müként benyújtott könyv tehát a teljességre törekszik: időben és térben feltérképezve az ipari forma tervezéselméletét és a termékformálás gyakorlatát. A rendelkezésre álló terjedelem 359 oldal, amihez 19 oldalnyi forrásjegyzék társul. (A benyújtott könyv magját a 20. századnak a húszas évektől a hetvenes évekig terjedő időszaka képezi, ami magyarázza, hogy miért túlreprezentált a hatvanas-hetvenes évek szakirodalma.) A könyvben az ábrák számozatlanok, de - tételes ellenőrzés nélkül is - biztosan jut minden oldalra legalább egy belölük. A szövegközi fekete-fehér illusztrációkat 16 teljes lapot betöltő színes tábla egészíti ki, amelyek egyúttal a fejezetek elválasztására is szolgálnak. A szöveget bőséges jegyzetanyag kíséri, a fejezetenként újrakezdődő számozást összesítve 803 tétel. A felsorolt számokon túl a szövegben szereplő rengeteg adat, név és évszám együtt azt mutatja, hogy a könyv müfajában nem is áll olyan távol az akadémiai doktori értekezéstöl.

A könyv - ahogy arra címe is utal - vezérfonala az időrend. A történet kezdőpontja 1750. Az évszám ugyan nem köthető egyetlen, a design történetét meghatározó eseményhez, a modern építészet történetének a kezdeteként azonban többnyire el szokták fogadni, és az ipari forma története mindig is szoros összefüggésben volt az építészeti mozgalmakkal. (A szakirodalom nem egységes a témában. A szerző által is hivatkozott Sigfried Giedion például a Bauen in Frankreich, Bauen in Eisen, Bauen in Eisenbeton címü, 1929-es írásában 1830-ra teszi az ipari fordulatot, míg a kimondottan a gépesítés témájával foglalkozó könyvében - Mechanization Takes Command - a futószalag bevezetésétől, nagyjából 1800-tól indítja a történetet.) A vizsgált 260 év természetesen nem egyenletesen fontos a fejlődés szempontjából: a modernizáció messzire nyúló történeténél a modern mozgalmak és a modernizmus jóval rövidebb múltra tekint vissza, a tudatos design pedig a modern mozgalmak szülötte. A minőségi váltásra a szerző is utal, elfogadva Maldonado, Kauffmann és Lindinger állítását, hogy az első professzionális ipari formatervező az építész Peter Behrens volt (106. oldal).

Ernyey maga is az (idézőjelbe tett) modern fogalmát viszi végig a három nagy fejezet címében: $A$ 'hosszu' '19. század, A 'modern' 20. század, A 'modern' után. A fejezetek eltérő terjedelme - a középső fejezet mintegy kétszerese az elsőnek, illetve a harmadiknak - ugyancsak a modern kiemelt szerepére utal. Előbbiekből következik, hogy a leggazdagabb anyag a „,modern” időszakából áll rendelkezésre, és - mivel a szerző is ezzel az időszakkal foglalkozik a legrégebben - ezen a téren nyújtja a legtöbb információt a könyv. A gyakorlati eredmények bemutatását itt kíséri a legtöbb elméleti hivatkozás, amit nemcsak a terület feltártsága, de az is indokol, hogy elmélet és gyakorlat talán ekkor volt a legszorosabb összhangban: a mindennapi tárgyak ipari elő́llításának az elfogadása nemcsak új formai lehetőségeket kínált a tervezők- 
nek, hanem - az új világlátás és korszellem mellett - a gépi gyártás által lehetővé tett szociális elkötelezettség erkölcsi fölényét is szemben az egyedi műveket alkotó müvészekkel.

A fenti harmónia nem volt érvényes „a hosszú 19. századra”, amit Ernyey is elismer a fejezet összefoglalásában. „A gyakorlat »stíluspluralizmusa«, továbbá az elmélet és a gyakorlat elkülönült fejlődése egyaránt meghatározó vonása az ipari tervezés e korszakának" (86. oldal). A fejezetbe sürün beszúrt 19. századi szövegidézetek épp ezért inkább megszakítják a történetet, mintsem segítik az összefüggések megértését. A századforduló és az azt követő évtized írásai már sokkal izgalmasabbak, egyre inkább manifesztumokat, illetve polémiákat ismerhetünk meg, amelyek a korabeli termékekkel összevetve kapnak igazán értelmet. Az ismert, a könyvben teljes egészében közölt Hermann Muthesius - Henry van de Velde-vita nemcsak a szokásos tipizáljunk-ne tipizáljunk alternatívák közötti választás érveit sorolja, de - és ez a design esetében különösen fontos - a kultúra közvetítésének két lehetséges útját is képviseli. Vajon a széles körben elérhető minöségi használati tárgyak kínálata segíti-e jobban egy nép általános kultúrájának a felemelkedését, vagy az, ha a felsőbb társadalmi rétegek adják a mintát, és a többiek öket követik? A 'modern'után címü harmadik fejezet első alfejezete $A$ hatvanas-hetvenes évek címet viseli. Az elméleti szövegek itt a címmel összhangban a hatvanas-hetvenes évekböl valóak és vegyesen képviselik a korszak megújuló, a rendszerelméleten alapuló tervezéselméleti-tervezésmódszertani gondolatait, illetve a már a modern kritikáját megfogalmazó trendeket. ( $A$ 'modern' után cím a hatvanas-hetvenes évekre vonatkoztatva némileg félrevezető. A modern-posztmodern korszakhatárt 1968-ra szokták tenni, a „modern után” - a továbbra is jelen levő bizonytalanságra reflektáló - elnevezést pedig a posztmodern elmúlása után, nagyjából a kilencvenes évektől használják, igaz, azóta az egész 1968 utáni időszakra alkalmazva.) A második alfejezet címe $A z$ ezredfordulón, amely - az előzőekböl következően - mintegy harminc évet tekint át. A periódus hosszához képest ebben a részben kevés a tervezéselméleti írás, amit csak részben indokol a jelentős, elmélettel is foglalkozó iskolák hiánya. Ami szöveg mégis bekerül a könyvbe, az jellemzően nem a szükebb ipari formatervező szakma, hanem inkább az ökofilozófia körébe tartozik. Az ökofilozófia a nyolcvanas-kilencvenes években valóban egyfajta célt, elöretekintést ígért a modernizmus nagy metanarratívái elvesztése után, míg az ökológiai szemlélet mára többé-kevésbé beépült a design gyakorlati alapkövetelményei közé. A felelős design manifesztumai közül viszont jó lett volna néhányat megismerni.

Az időrend követésén túl a 260 éves történet tagolásához további szempontokra is szükség van. Ernyey két eszközt alkalmaz: egyrészt a területek, országok, másrészt a stílusok, trendek szerinti tárgyalást. A design történetét felvezető 19. század vizsgálatánál a vezérfonal a területenkénti bemutatás. Ezt indokolja az egyes országok eltérő fejlettsége, iparosodottsága, technikai színvonala és nem utolsósorban kultúrája. (Az építészettörténet is sokáig hasonló módon dolgozta fel a 19. századot, bár az utóbbi években született a jellemző témák és az országok tárgyalását vegyítő munka 
is.) A szerző az ipari termékforma szinte teljes körének a történetét kívánja feldolgozni. „Elsősorban a konkrét gyártmányokat, az egyes korszakok jellegzetes terméktípusait és az őket közvetlenül meghatározó terméktervezés-elméleti eredményeket elemzem... vizsgálatomat elsősorban a használat által leginkább meghatározott tartós fogyasztási cikkekre és mindennapi munkaeszközökre szükítem" (16. oldal). A vizsgálatba vont tárgyak bősége és a történet országonkénti „újrakezdése” következtében viszont egy-egy termékcsoport története szétesik, fejlödésük - megjegyzésem továbbra is a 19. század bemutatására vonatkozik - nem követhető. A könyv második és harmadik részében nagyobb szerepet kapnak az egyes, megnevezett irányzatok (Art Nouveau, funkcionális forma, funkcionalizmus, avantgárd, neoavantgárd stb.), ami segíti az olvasót a szerző gondolatainak a követésében. Az országonkénti tárgyalás persze továbbra is jelen van, ami különösen akkor megnyerö, amikor az úgynevezett „nagy design nemzetek” bemutatása mellett a hazai ipari formatervezők munkái és eredményei is - teljesen joggal, mert nemzetközi szintet értek el - helyet kapnak (308-313. oldal).

Ernyey Gyula a termékformálás gyakorlatának és elméletének a történetét dolgozza fel. Az ipari formatervezésnek számos mühelye volt, amelyek meghatározó szerepet játszottak a design müvelésében és terjesztésében. A Deutscher Werkbund, a Vhutemasz, a Bauhaus vagy a később alakult iparmüvészeti iskolák és a nagy gyáraknak dolgozó tervező-fejlesztő csapatok mellett azonban fontos tényezők voltak a további fórumok is: a designnal foglalkozó folyóiratok, kiállítások, vásárok és szakmai szervezetek. Ezekről itt-ott esik is szó, de talán megérdemeltek volna egy külön fejezetet.

A doktori munka külön füzetben tartalmazza a szerző téziseit. A nyolc tézis - az első kivételével, amely evidenciákat tartalmaz - lényegében megegyezik a könyvben az egyes fejezetek végén közölt összefoglaló megállapításokkal. Az egyes tézisek igazolását így a könyv megfelelő fejezetében kell keresni - bár hivatkozásként több helyen a szerző korábbi könyvei szerepelnek. A megállapítások - lévén történeti munkáról szó - jellemzően leíróak, amelyek újdonságértékét a tárgyuk adja, hogy tudniillik az ipari termékformálásra vonatkoznak, azt helyezik el a tágabb technikai, gazdasági és kulturális környezetben. A másodiktól a nyolcadik tézist a fentiek alapján lényegében elfogadom. Ugyanakkor vitatom az 5 . tézisben megfogalmazott egyik állítást, mely szerint a (szociális tartalmú) funkcionalizmussal szembe lehet állítani a „kereskedelemorientált" stylingot, különösen, hogy a 6. tézisben a második világháború utáni időszak kapcsán már épp a szerző ír a „mélyebb szociális tartalmától megfosztott”, „kiterjesztett funkcionalizmusról”. Legalább Lewis Mumford 1949-es írása (Monumentalism, Symbolism and Style, The Architectural Review, 1949 április) óta meg kell fontoljuk, hogy a funkcionalizmusba nemcsak a fizikai szükségletek, hanem minden további emberi funkció is beleértendő, vagyis a használó pszichológiai, társadalmi és személyes, sőt szimbolikus tartalom, üzenet iránti igénye is.

Fentiek alapján Ernyey Gyula benyújtott doktori értekezését nyilvános vitára alkalmasnak tartom. 


\section{ERNYEY GYULA VÁLASZA AZ OPPONENSI VÉLEMÉNYEKRE}

Mielött dolgozatom bírálatainak tételes megválaszolásába kezdenék, szeretnék néhány szót szólni munkám megértését elősegítendő indulásáról és iniciátoráról: Pogány Frigyes professzorról. 1967 szeptemberében, mint a Moholy-Nagy Művészeti Egyetem egykori jogelődjének, a Magyar Iparművészeti Főiskolának vezetőjétől, kaptam megbízást - Simon Mariann szép kifejezésével élve - a „szerethető építészetelmélet" alapján kimunkált általános környezetesztétika részeként, az Ipari Formatervező Tanszék által müvelt szakterület történetének oktatására. A feladat kiváltságos és megtisztelő volt egy tervezői diplomával rendelkező fiatal számára. Szépsége mellett azonban a nehézsége sem volt kisebb, hiszen ez a tantárgy mindaddig nem létezett Magyarországon, és mint tudjuk, a világban sem, legalábbis nem a szerszám- és gépipari formatervezésre kimunkálva. Mivel nem volt ilyen tudás, nem volt mit összefoglalni és oktatni, így meg kellett kísérelnem annak összegezését, amit tudni kellett volna. Ez irányú kutató- és oktatómunkám azóta is tart, hiszen napról napra óriási mértékben növekszik a különböző céllal és módon készített ipari tárgyak világa, változnak tervezésük és megítélésük szempontjai. Legfrissebb öszszegzésük áll most Önök előtt.

Mindenekelött szeretném megköszönni a doktori müként benyújtott könyvem bírálóinak: dr. Bonta Jánosnak, dr. Simon Mariannak és dr. Sisa Józsefnek átfogó és alapos értékelését. Különösen hálás vagyok dr. Bonta Jánosnak, hogy magas kora ellenére elvállalta a felkérést, mivel munkám nemcsak óriási témát és hosszú időtartamot ölel fel, de mennyiségileg is próbára tevő, nem kis fáradságot igényel alapos áttanulmányozása. Bírálatukban számos közös elem található, nem utolsósorban, hogy müvemet értékei alapján vitára alkalmasnak találták, sőt „nagyszerủ könyvnek” (Bonta), „hazai téren egyedülálló vállalkozásnak” (Simon) nevezték, „egy szakmai pályafutás egészének egyfajta összefoglalásának" (Sisa). Sisa József azt is hangsúlyozza, hogy a „kötet jól áttekinthető és logikusan strukturált: a történettudományi szakmunkák bevett rendszerét követve kronologikus felépítésü”, szerzője „az interpretálási módszerek igen széles tárházával operál. Igénybe veszi a tágabb történeti, filozófiai és eszmetörténeti szempontokat, sőt felhasználja a kulturális antropológia módszereit is". (Sisa 349. és 350. o.) Köszönöm könyvem egészére vonatkozó elismerésüket és a részletekre vonatkozó bírálatukat. Mivel észrevételeiket mindhárman a történeti felépítés mentén tették meg, azokra együttesen adok választ, lehetöség szerint összefogva a közös felvetéseket és csak a vitára késztetőkkel, a részemröl részletesebb kifejtést igénylőkkel foglalkozom tételesen.

Dolgozatom könyvformáját ugyan a Doktori Szabályzat lehetővé teszi, mégis eléggé szokatlan a használata a müszaki tudományok müvelöi körében. Mindhárom bírálóm szóvá is tette ezt. Témám erős vizuális vonatkozásain túl azonban többet szerettem volna letenni bírálatra egy hagyományos traktátusnál; egy valóságos ipari tárgyat, még inkább épületet, a „gondolatok házát”, amely nemcsak elvi, hanem konkrét, érzéki megoldása is a gyakorlati és eszmei kérdéseknek, és amely - mint egy korszerü épület vagy tárgy - maga is változhat az igények változásával a fó 
szerkezeti elemek, a gondolati váz lényeges megbontása nélkül. A tartalom szükség szerinti felépítése, tagolása mellett, a gondolati struktúra használhatóságának elősegítésére készítettem a főszöveg, jegyzetek és képek - fehér-feketék és kiemelő színesek - párhuzamosan futó, reményeim szerint egymást és a megértést erősítő rendszerét. Úgy vélem, és Sisa József elismerő szavai ebben erősítenek, hogy ez a szövedék több és pontosabb annál, mint amit témám kéziratos formájában tudtam volna nyújtani bírálóim számára. Sisa József könyvem tudományos apparátusával (részletes jegyzetapparátus és terjedelmes, kategóriákra tagolt bibliográfia) és vizuális megjelenésével (a „sok száznyi kép bőségesen és a kellő helyen, a megfelelö helyre tördelve szerepel a kötetben”) kapcsolatos pozitív észrevételeit (352. o.) mint szerző és tervező egyaránt köszönöm.

A könyvforma mellett a címoldalt illetően is magyarázattal tartozom, annál inkább, mivel opponenseim szintén foglalkoztak vele. Sisa József rámutatott, hogy magában a címben már felsejlik témám terminológiai bonyolultsága. Valóban így van, bár mára a világ iparilag fejlett államaiban általában elterjedt az ipari forradalom elején, a 18. század vége felé Nagy-Britanniában megjelent design megnevezés (ritka kivétel a német Gestaltung, illetve Formgestaltung használata, az időnként megjelenő nemzeti helyesírás szerinti írásváltozatok mellett), mégis nehezen szántam rá magam hazai alkalmazására. Ugyanis elterjedtsége ellenére nemcsak az idő során voltak különböző értelmezései, hanem ma is vita folyik tartalmáról és terjedelméröl a hazai és külföldi szakirodalomban egyaránt, amelynek bemutatásával bővebben foglalkoztam könyvem első fejezetében. Ennek látványos drámája zajlik ma Magyarországon. A küzdelem, amely Kossuth Lajosnak a születő magyar gyáripar termékeire alkalmazott iparmüvészet megnevezésével indult 1842-ben, a gépi iparmüvészet, majd az ipari müvészet, még később az ipari forma(tervezés) használatán keresztül jutott el napjainkig, az „,ipar nélküli ipari formatervezés idejéig”. Ma „a kreatív ipar" varázsszavaként hódít, ráadásul az elterjesztését erősítö-illusztráló magyar(os) helyesírással: dizájnként. Az igazi gond ezzel az, hogy az összetett tartalom helyett leszúkített felfogást, a szakirodalomban stylingként ismert jelenséget és tevékenységet, legfeljebb müvészi „termékkozmetiká”-t propagálnak vele. (A régóta aktuális papaneki Design for the Real World program, a nagyságrendileg súlyosabb, távlatosabb, a fenntartható fejlődést szolgáló komplex terméktervezés és tervezésetika helyett.) Ezért a magam részéről egyelöre maradnék - a korántsem problémamentes, de mégiscsak valamennyire bevált - eredeti angol írásmód és a nemzetközi szervezet általi értelmezés mellett - továbbpontosítva azt a szövegkörnyezetben.

Témám időtartamának számokkal való jelölése a címoldalon ugyancsak magyarázatot igényel, bár úgy gondolom, hogy nem ment az igazság rovására. Egész munkámban az események - a tárgyalkotás - folyamatáról beszélek mindvégig, az évszámokat csak a címekben és címlapo(ko)n (a gyors felismerés és a könnyü rögzítés céljával) használható rövid írásmódnak - jelkép(ek)nek - tekintettem és tekintem ma is, nevezetesen az ipari forradalomtól napjainkig terjedő időszak tömör megjelölésére. Ugyanis még e hosszabb megfogalmazás sem lenne pontos és kielégítő, hiszen nemcsak az építészet vonatkozásában - mint arra Simon Mariann rámutatott bírála- 
tában -, hanem a különböző tudományterületek művelöi között is különböző évszámokkal találkozunk a soktényezős ipari forradalom kezdeteit illetően. A különböző erők és történeti események hosszú évek összehasonlító vizsgálatai után döntöttem a témámhoz legközelebb álló, legátfogóbb, legfrissebb és nemzetközi kutatócsoport által (E. Castelnuovo et al: History of Industrial Design 1750-1830: The Age of Industrial Revolution, 1990) konszenzussal kimunkált és használt 1750 elfogadása és megjelenítése mellett - a címlapon. A szövegtestben azonban továbbra is - mindvégig - megmaradtam a hosszú folyamat, mégpedig különböző idejü és tartalmú hosszú folyamatok hangsúlyozása mellett.

Az ipari forradalom indulásának kérdésével rokon a design kezdeteinek és első képviselöinek megítélése. Ha széles körben evidenciának fogadnák el azt a könnyen belátható tényt, miszerint gyártmányok forma nélkül nincsenek, hiszen valóságuknak, megjelenésüknek feltétele a forma, még akkor sem lenne egyszerü egyetérteni a kérdés megválaszolásában. Ugyanis a kézművességekből kinövő gyáriparban a mindennapi használati és termelőeszközök alapvetően a tervezö-gyártó mesteremberek közül kinőtt feltalálók által készültek sokáig, és csak a korszakok szerinti státusszimbólumok szempontjából fontos, leginkább a lakáskultúra körébe sorolható gyártmányoknál igényelték - nem az alapforma, hanem - a díszítmények, az ornamentika alkotóinak megnevezését (pl. Wedgwoodnál a szobrász John Flaxman nevét). Még hosszú időnek kellett eltelni, ameddig a díszítésmentes forma széles körü esztétikai elfogadást nyert, és ebben az előrehaladásban bonyolult folyamatok játszottak közre. Kétségkívül egyik korai képviselöje - legalábbis a vezető brit iparban - Christopher Dresser a 19. század hetvenes-nyolcvanas éveiböl, de csak a lakáskultúra hagyományos területeiről. Ilyen módon a korszakot reprezentáló új tárgyak, a villanyárammal müködő fogyasztási cikkek körében joggal nevezi úttörőnek a (német) szakirodalom a német Peter Behrens harminc évvel későbbi tevékenységét az AEG-nél, sőt még újabb harminc évnek kellett eltelnie, amikor megjelentek az első ismert formatervezők az európai és amerikai gépiparban. Viszont jól tudjuk, hogy az ipari forradalom valóban fontos, formailag is kiérlelt és máig használt nagy példányszámú, így a Windsor-szék, Thonet-bútor vagy az egészségügyi papirpohár és mások már jóval hamarabb megszülettek, a design hivatalosan elismert képviselőinek jelentkezése elött.

Tisztázandó alapkérdésként merült fel Bonta János részéről - kutatásaim egészének méltatása mellett - az építészet, illetve design fogalmainak helyenkénti egymásba átmenete, összemosódása. Ez egy régen élö, összetett kérdéskör, amelyre még egy-egy tervező és teoretikus különböző pályaszakaszaiban is különböző válaszokat találunk, példa rá Victor Papanek kezdeti és késői munkássága. Megítélésem szerint az építészet és a tárgyalkotás a legrokonabb alkotói tevékenységek, amelyek tervezési munkamódszerükben, de még összetett (anyagi és szellemi) alapvető céljaikban is rokonok. Nem véletlenül igen sok ismert építész található a jeles ipari tárgyalkotók sorában: Gottfried Sempertől és Friedrich Schinkeltől Charles Rennie Mackintoshon, Peter Behrensen, Marcel Breueren és Le Corbusier-n és Alvar Aalton át Ettore Sottsassig, Robert Venturiig, Michal Gravesig bezáróan, csupán a klasszikusok közül 
válogatva. Végső soron azonban a tér- és tárgyalkotás - minden rokonsága ellenére - eltér egymástól: az előbbinek „,célja és eredménye a tér” (Cságoly Ferenc), míg az utóbbinak a térben megjelenő tömegforma, pontosabban ,az ipar által termelt tárgyak formai minőségeinek meghatározása" (Tomás Maldonado). A köztük levő kapcsolatok azonban szövevényesek és változóak az ókortól a középkoron át napjainkig, Egyiptomtól Európán és Amerikán át Japánig találunk rá különböző tárgyi és elmélettörténeti példákat. Az ipari tárgyalkotás koronkénti sajátosságainak számbavétele ebben tisztázó lépés lehet. Munkámban csak az egyes korszakok témámhoz közeli építészeti eredményeivel foglalkoztam: a francia forradalmi építészet, a paxtoni kristálypalota, a tatlini szoborépítészet, a De Stijl és a Bauhaus, valamint a Neues Frankfurt program épületei, a Pompidou-központ és mások példázzák. Mindezek témám tervezéstörténetét befolyásoló-meghatározó minták, és nem vállalkoztam az építészet és a design közötti bonyolult és hosszú kapcsolatok feltérképezésére. Mindazonáltal köszönöm Bonta János professzor nagy ívü építészeti példaállítását, és az építészeti hasznosság szépséggé válására Le Corbusier kora szellemét örző szép idézetét, amelyhez a magam részéről a NASA elgondolkodtató „Skylab” ürlaboratóriuma (1968-1973) példáját illeszteném. Műszakilag és ergonómiailag tökéletesen kimunkált ipari tárgy és munkahely volt mindaddig, amíg - a Raymond Loewy-féle designiroda javaslatára, a müszaki tervezők egyöntetű tiltakozása ellenére, az ürhajósoknál gyakran fellépő klausztrofóbia leküzdésére - kilátást biztosító nyílást nem vágtak a komp burkolatába. Ezáltal viszont a tervezők nem csupán stresszoldó megoldást találtak, de megsokszorozták az ürhajósok munkateljesítményét a munkahely munkatérré tágításával, olyan térélménnyel ajándékozva meg őket, és rajtuk keresztül az emberiséget, amit addig soha, senki nem érzett, nem látott korábban. Olyan volt, mintha bepillanthattak volna a túlvilágba (pedig csak a Földön kívüli világba láthattak), de legalábbis újraérezhették a középkor emberének a katedrálisok fényben úszó gyönyörủ ablakai által kiváltott megrendülését.

Sisa József nehezményezte, hogy a magyar ipari tervezők teljesítményének bemutatása nem elég hangsúlyos dolgozatomban. Szándékom szerint munkám az egyetemes gyártmányfejlődés története föbb eseményeinek számbavétele. A magyar fejlödéssel már több ízben foglalkoztam más - általa is idézett - könyvemben. Mindazonáltal az egyes helyeken, amikor úgy ítéltem, hogy a nemzetközi megoldásokkal egyenértékủek a hazai eredmények, és segítené a fejlődés megértését, a tájékozódást a korban, természetesen szerepeltettem őket. Így került sor az első részben a kitünő Zipernowsky Károly és a Ganz-gyár, a másodikban a Bauhaus magyar mesterei mellett megint csak a Ganz-motorvonatok tervezőinek, majd a hatvanas-hetvenes években súllyal a tervezés-oktatás, a századvégén Rubik Ernő szerepeltetésére, de e sorból is kitetszik, hogy gyáriparunk produkciója teljes egészében nem, csak egyes területein volt mérhetö az élenjárókéhoz. Ismert, hogy legjobb tervezőink (Galamb Józseftől Breuer Marcellon át Pavlics Frencig) külföldön tudták kibontakoztatni leginkább képességeiket. Természetesen ismerek olyan munkát magam is, így az észt Krista Kodres professzor bútortörténeti könyvét (Ilus maja, kaunis ruum, 2001), amelyben az egyetemes és az észt példák egymás mellett, pontosabban egy- 
más után találhatók. Ez egy beszükített témában sokkal inkább járható eljárás, mint az ipari tárgyak igen változatos világában. Természetesen nem vitatom, hogy témám vizsgálata más arányok és feldolgozások szerint is lehetséges.

Dolgozatom egész felépítését, méretezését illetően Simon Mariann joggal észrevételezte, hogy legsúlyosabb része a „modern”, pontosabban fogalmazva a Modern Mozgalomé. Hiszen nemcsak a szakma szélesebb körü kialakulásának, hanem magának az ipari termelés szédületes felfutásának ideje ez, nem mellesleg két világháborúval és két világrendszer kialakulásával terhelve. Ráadásul az első ipari forradalmat megalapozó gőzenergiát ez időben váltotta fel a napjainkat is meghatározó villamos energia - új utakat nyitva a fejlödésnek. Ugyanakkor nem csupán a modernt megelöző és követő korszakokként vizsgáltam a hosszú 19. századot, illetve az ezredfordulót, hanem önálló, saját értékkel bíró fejlödési szakasznak az ipari tárgyalkotás folyamatos történetében. Az ipari forradalom alapozta meg közvetlenül mindazt a kultúrát, amiben élünk a müszaki, gazdasági, mezőgazdasági és egészségügyi forradalmi változásoktól kezdve egészen a múvészetek változásáig. A 20. század utolsó harmadától pedig olyan változások kezdődtek az információs technika, az újabb forradalom szédületes hódításával és vele együtt a különféle fizikai és eszmei határok ledöntésével, amelyek alapvetően megváltoztatták korábbi világképünket, sőt magát a világot is. Mindazonáltal Simon Mariann joggal fogalmazta meg maga is a „,modern kor” megkülönböztető súlyát és fontosságát: „Elmélet és gyakorlat talán ekkor volt a legszorosabb összhangban: a mindennapi tárgyak ipari elöállításának az elfogadása nemcsak új formai lehetőségeket kínált a tervezőknek, hanem - az új világlátás és korszellem mellett - a gépi gyártás által lehetővé tett szociális elkötelezettség erkölcsi fölényét is szemben az egyedi müveket alkotó müvészekkel.” (Simon 353-354. o.)

Az egyes korszakokkal és fejezetekkel kapcsolatban is több kérdést vetettek fel bírálóim. Időrendben haladva, Sisa József a historizmus mélyebb vizsgálatát hiányolta témaismerete szerint méltán. Különösen a posztmodern óta, amikor is e korszaknak jelentős átértékelése történt, de az ezredforduló és a 19. század végének számos hasonlósága miatt magam is másként látom az értékeit, mint ahogyan tanulmányaim idején voltak ismertek. Tényszerüen állíthatom, hogy a nemzetközi szakirodalom átfogó designtörténeti munkáinál jóval nagyobb mértékben foglalkoztam a 19. század és a historizmust is magába foglaló stíluspluralizmus vizsgálatával. Ugyanakkor a historizmus és kora szerepe között jelentős különbséget találok az ipari tárgykultúrában. Témám területén a historizmus szerepe jelentős mértékben különbözött attól, ahogyan az építészetben érvényesült, ahol látványos óriási építkezések, napjainkban is müködő monumentális középületek kötődnek hozzá. Ebben az időszakban az ipari kultúra területén egymás mellett futottak a különböző - nem is stílusbeli, hanem alapvetően különböző értelmezés szerinti - tervezési irányzatok, úgymint a funkcionális és a reprezentatív törekvések. A korszak messze mutató új tárgyai, különösképpen a munkaeszközök, így Henry Maudslay forradalmi fémforgácsoló esztergái, James Nasmyth munka- és erőgépei, a gőzerővel müködtetett vonatok és hajók, a sok-sok új müszer, eszköz: író- és varrógépek, kerékpárok, hang- és képrögzítő esz- 
közök müszaki újdonságértékükkel hatottak föként, és történeti stíluselemek nélkül reprezentálják ma is korukat. Mindazonáltal a funkcionális irányzatú tárgyaknál is gyakran tetten érhetők a historizmus formaelemei. A század legismertebb - máig élő - Thonet-bútorainak barokk és biedermeier kapcsolatai, William Morris és körének a középkori múvészet iránti csodálata vagy a brit ipari formatervezés úttörőjeként tekintett Christopher Dressernek erős orientális, jelesül japán, avagy a szecesszió Charles Rennie Mackintosh-nak az ősi kelta müvészettel való szoros kötelékei közismertek, és magam sem felejtettem az egyes alkalmakkor jelezni azokat. Mindezek mellett a historizmus szerepe a tárgykultúrában megítélésem szerint ellentmondásosabb, mint az építészetben, különösen, mint az európai - súllyal közép-európai nagyvárosokat, így fővárosunk felépítését is megalapozó urbanisztikában. Ráadásul az egyetemes historizmus korának és egyes területeinek részletesebb kritikai feltárása az ipari tárgykultúrában csak újabban kezdődött meg - nem véletlenül - a fiatalabb kutatónemzedék révén, jelentős mértékben a Design History címü nemzetközi folyóirat szerzői által.

Ide kapcsolódik az ornamentika kutatására vonatkozó észrevétele ugyancsak. (351. o.) Magam is úgy látom, hogy az ornamentika kortárs reneszánsza még inkább sürgeti a 19. század utáni szerepének pontosabb megismerését. Hiszen nemcsak a modernizmus egyes korszakaiban és helyein volt igen felemás a megítélése, hanem föként a modernizmuson kívüli területeken. Mindezekről ma még keveset tudunk. Különösen érdekes és látványos eredmények várhatók az ideológia és az ornamentika kapcsolataira irányuló kutatásoktól, amelyek feltárására eddig jobbára csak a divattörténetben történtek kísérletek.

A fentiek alapján teljesen egyetértek Sisa József azon megállapításával is, miszerint még jobban megvizsgálandó az ideológia szerepe a 20. századi ipari tárgyalkotásban. A szovjet avantgárd erős politikai hátterének ismeretén túl a nemzeti szocializmus, és egyáltalán a diktatúrák hatásának kutatása legalább annyira fontos, saját történelmünk a legközvetlenebb példa rá. Csupán szeretném jelezni, hogy erre magam is tettem már kísérletet dolgozatom „Az építő avantgárd” és a „Klasszikus funkcionalizmus" címü fejezetében, majd az ezredfordulóról szóló fejezetekben. Ezeknél használtam is a német (Scheerer, Form, 1975) és az angol nyelvủ designtörténeti publikációk (Aynsley 1993; Woodham 1997 és e kérdéssel behatóan foglalkozó Crowley 1993, 2002) legfontosabb megállapításait. De nem lehet eléggé hangsúlyozni az ez irányú kutatás fontosságát. A teoretikus megfontolások mellett a mindennapi élet jelenségei és az információs csatornákon keresztül szünet nélkül érkező gazdaságpolitikai hírek egyaránt megállás nélkül figyelmeztetnek meghatározó súlyára.

Különösen figyelemreméltónak és megszívlelendőnek találom Sisa Józsefnek a komfortkutatásokra vonatkozó javaslatát az ipari tárgykultúra területén (351. o.), amely egyaránt alapkérdése a tárgy- és tértervezésnek. Siegfried Giedion általam is sokat használt, kitünő korai összegezése (1948), Reyner Banhamnek a modern építészet történetének a hagyományostól messze eltérő megközelítése (Architecture of 
the Well-tempered Environment, 1969) és folytatásuk: Adrian Forty (1995) könyve mérföldkövei e téma felderítésének. A feladat szerteágazó nagysága, ráadásul kultúrafüggő megítélése, illetve megjelenése miatt azonban még hosszú, összetett vizsgálatokat és sokszínü teammunkát igényel mélyebb feltárása.

A ,modern kor"'-t illető pro és kontra észrevételek mellett a modernt megelőző és követő korszakokra vonatkozóan kaptam a leginkább megszívlelendőket, jóllehet jelenlegi eljárásaimat meg tudom indokolni mindkettőben. Napjainkat illetően egyetértek Simon Mariannal, hogy a mintegy három évtizedet átfogó ezredfordulós fejezetben kevés a tervezéselméleti írás, és ami található, az is inkább az ökofilozófia körébe tartozik. Valóban úgy tünik, hogy a modern korszakot jellemző gyakorlat-elmélet szoros együtt járása nem korszakunk sajátossága számos bonyolult elvi és világos gyakorlati ok miatt sem. A modern elutasítását hirdető nagyhatású müvek után (gondolok Jencks és Venturi könyveire, de még inkább Papanek világsikerü munkáira) nem születtek hasonlók, mégpedig alapvetően a meghirdetett célok valóra váltásának mindennapi nehézségei miatt. Meghirdetni ugyanis könnyebb, mint megvalósítani és elterjeszteni őket. A szorító szociális gondok és a fenntartható fejlődés helyi megoldásainak kísérlete, nehéz és vizuálisan sokszor kevéssé vonzó aprómunkája igen különbözőképpen folyik a mindennapokban. A felelösségteljes design valóban új manifesztumai közül jó lenne igazán néhányat megtalálni a tisztánlátás elősegítésére.

Simon Mariann azon felvetésére is itt reagálnék röviden, hogy a designnal foglalkozó folyóiratok, kiállítások, vásárok és szakmai szervezetek talán megérdemeltek volna egy külön fejezetet. Mindezek szerepét magam sem becsülöm le az ipari tárgytervezés történetének alakulásában, ezért minden fontosabb helyen meg is emlékeztem róluk az Art Journaltól és az első (londoni) világkiállítástól kezdve a szecesszió folyóiratain, a párizsi, a New-York-i világkiállításokon át a milánói triennálékig és a szakterület nemzetközi szervezete, az ICSID szerepéig bezáróan. Mindazonáltal csak megismételni tudom alapvető célomat, miszerint az ipari termékalakításnak a gyártmányokban megvalósult formai minőségnek feltérképezése volt az elsődleges célom. Így - egyébként sok más mellett - ezeknek a fontos szerepü intézményeknek, orgánumoknak önálló tárgyalására sem vállalkoztam, de mindenképpen megfontolandónak ítélem javaslatát egy következő munkánál.

Simon Mariann figyelme kiterjedt könyvem összegezését tartalmazó téziseimre is. Jól ismert az építészet- és művészettörténetből, hogy az alkotók nem mindig úgy summázzák munkájukat, nem azt emelik ki belőle értékként, mint bírálóik. Viszont alapvetően egyetértünk abban, hogy a felfedezések és új megoldások jelentős része származik abból a tudományokban és a müvészetekben, hogy egyes elvek, ismeretek és eljárások egyik területről a másikra átkerülve nyernek új alkalmazást és igazolást, értelmet és értéket. Csupán arra szeretnék utalni, hogy 5. tézisem megítélésekor figyelmen kívül hagyja dolgozatomnak a kérdést részletesen bemutató fejezeteit és a bennük ismertetett nemzetközi szakirodalmat. Tudjuk, hogy mind a ,kereskedelemorientált" tervezésnek (styling), mind a (szociális tartalmú) funkcionalizmusnak különböző korszakai voltak, de nemcsak a klasszikus kor nagy tervezői (Loewy: 
Selling through Design kontra Dreyfuss: Designing for People) álltak egymással szemben programjaikkal és munkáikkal, de még a Doblin-féle enyhébb megfogalmazás szerinti styling és a 6. tézisben szereplő „,kiterjesztett funkcionalizmus” értelmezése is. Természetesen semmilyen gyáripari tervezés, így a funkcionalizmus sem lehet alapvetően kereskedelemellenes, ahogyan a styling is különböző időszakaiban és megoldásaiban eltérő minőséget képviselhet, de mindez végül is a kétféle tervezési megközelítésen nem változtat érdemben. Ráadásul az általam is nagyra becsült Lewis Mumford humanista hittel fogalmazott sorai sem módosítanak, hiszen ő valójában a jövőbeni modern épitészettől elvárható értékekről beszélt a Simon Mariann által hivatkozott 1949-es írásában: ,as modern architecture matures, it must become (kiemelés tölem!) multi-functional, giving increasing weight to biological, psychological, social, and personal criteria." (Mumford i. m. 178-179.) Mumford tehát a modern építészet jövőbeni kiteljesedéséről írt, magam pedig a legyártott, valóságos ipari termékekről készítettem értékelést.

Végül szeretném újra kifejezni öszinte köszönetemet opponenseimnek gondos értékelő munkájukért. Egyaránt köszönöm mindnyájuknak, hogy behatóan foglalkoztak dolgozatommal, feltárták értékeit és hiányosságait. Az előbbiek megerősítései erőfeszítéseimnek, míg az utóbbiak ismerete segítségemre lehet a továbblépésben. 